\title{
Research Paper \\ Comparison of the Effect of Executive Functions Training and Barkley's Model on Reading Performance and Academic Self-Concept in Students with Dyslexia
}

\author{
Emad Yousefi ${ }^{1}$, Salar Faramarzi ${ }^{* 2}$, Mokhtar Malek Pour ${ }^{3}$, Ahmad Yarmohammadian² \\ 1. Ph.D. Student of Psychology and Education of Children with Special Needs, Faculty of Psychology and Educational Sciences, \\ University of Isfahan, Iran \\ 2. Associate Professor, Department of Psychology and Education of Children with Special Needs, Faculty of Psychology and \\ Educational Sciences, University of Isfahan, Iran \\ 3. Professor, Department of Psychology and Education of Children with Special Needs, Faculty of Psychology and Educational \\ Sciences, University of Isfahan, Iran
}

Citation: Yousefi E, Faramarzi S, Malek Pour M, Yarmohammadian A. Comparison of the effect of executive functions training and barkley’s model on reading performance and academic self-concept in students with dyslexia. Quarterly Journal of Child Mental Health. 2020; 6(4): 5162. http://dx.doi.org/10.29252/jcmh.6.4.6

\section{A R T I C L E I N F O}

Keywords:
Dyslexia, executive
functions,
Barkley's model,
academic self-concept

Received: 7 Aug 2018

Accepted: 8 Mar 2019

Available: 1 Mar 2020

\section{A B S T R A C T}

Background and Purpose: Dyslexia is one of the most common and important reading disorders among children, characterized by problems with word decoding, poor ability in phonological processing skills, and various problems with the written language. The purpose of the present study was to compare the effect of executive functions training and Barclay's model on reading performance and academic self-concept in students with dyslexia.

Method: This research is a quasi-experimental research. Accordingly, 45 students with dyslexia were selected from among the students of third grade primary school in Bandar Abbas in the academic year of 2016-2017 and randomly assigned into 3 groups of 15 students (two experimental groups and one control group). The Reading Performance Questionnaire (Abedi, 2016) and the Academic SelfConcept Questionnaire (ASCQ) (Yi- Hsin Chen, 2004) were used to collect data in two pre-test and post-test stages. The Barclays Model Practices and executive functions education was given to the participants in the first and second experimental groups respectively in 7 sessions, but the control group did not receive any intervention.

Results: Results of univariate analysis of covariance showed that executive functions intervention and Barclay's intervention had significant effect on reading performance and self-concept of students with dyslexia in general. Also, the results of multivariate analysis of covariance showed that both interventions had significant effect on the dimensions of reading performance and academic selfconcept, but training of executive actions had more effect on both dependent variables ( $\mathrm{p}<0.05$ ). Conclusion: Given the effectiveness of executive-based intervention in comparison with Barclay's model in students with reading disorder, it can be explained that the components of executive functions such as working memory, planning, and mental organization are very closely related to reading skills and thus increase their level of self-concept.

\footnotetext{
* Corresponding author: Salar Faramarzi, Associate Professor, Department of Psychology and Education of Children with Special Needs, Faculty of Psychology and Educational Sciences, University of Isfahan, Iran.

E-mail addresses: S.faramarzi@edu.ui.ac.ir
} 


\title{
مقايسه تأثير آموزش كنش هاى اجرايى و مداخله مبتنى بر التوى باركلى بر عملكرد خواندن و خودينداشت تحصيلى

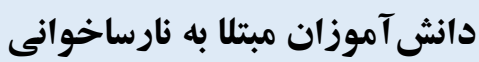

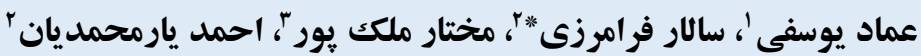

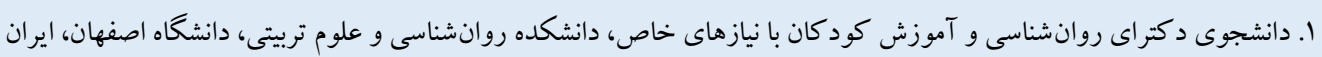

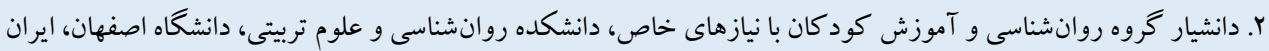

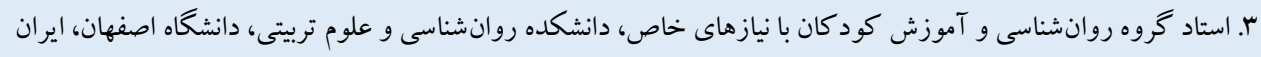

زمينه و هدف: نارساخو انى كه از شايع ترين و مهم ترين اختلال هاى خو اندن در بين كو د كان است، با مشكلاتى در رمز كثايى كلمه، توانايى

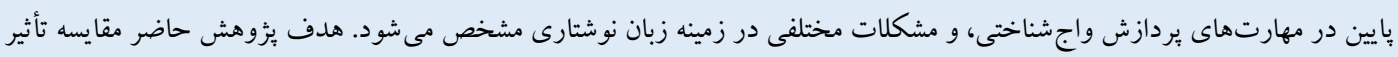

آموزش كنشهاى اجرايى و الكوى بار كلى بر عملكرد خو اندن و خودينداشت تحصيلى در دانش آموزان مبتلا به نارساخوانى است.

مشخصات مقاله

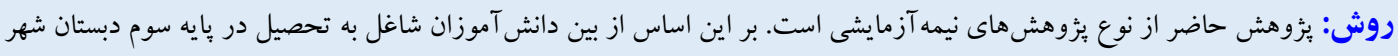

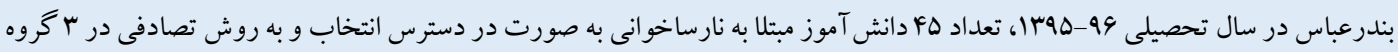

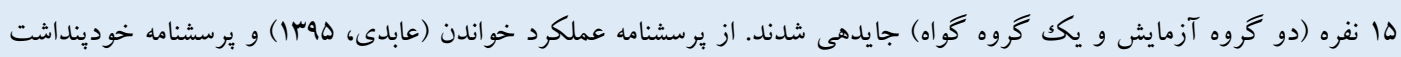

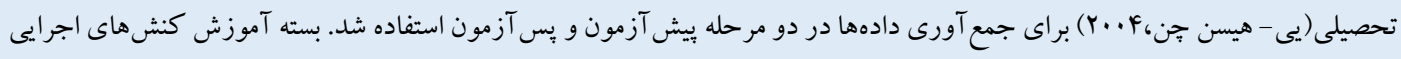

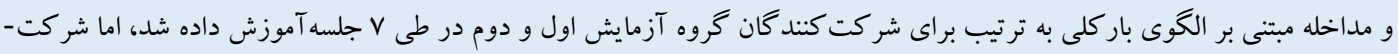

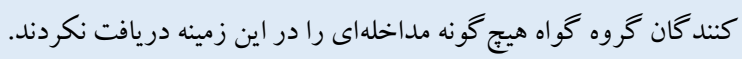

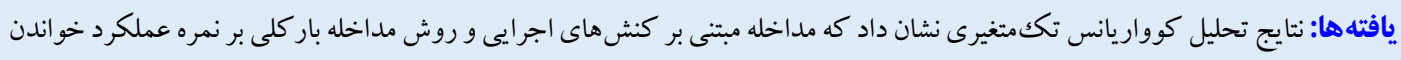

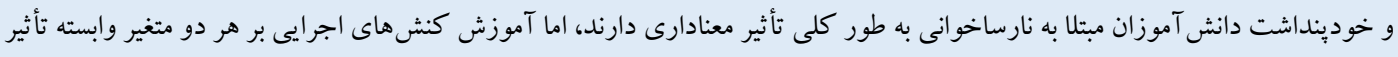

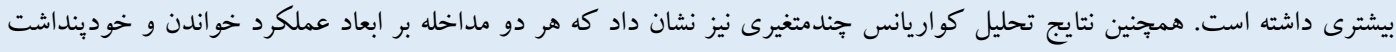

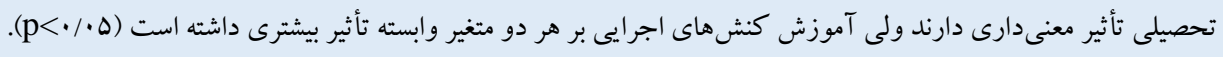

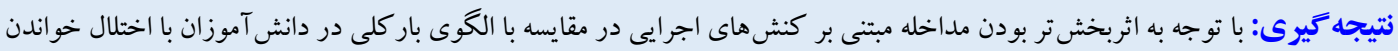
دريافت شده:

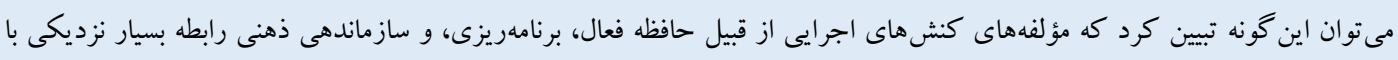

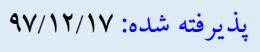

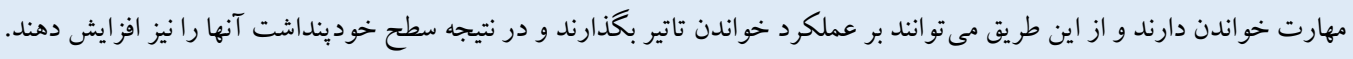

منتشر شده:

* نويسنده مسئول: سالار فرامرزى، دانشيار گروه روانشناسى و آموزش كود كان با نيازهاى خاص، دانشكده روانشناسى و علوم تربيتى، دانشكاه اصفهان، ايران.

رايانامه: E-fathiazar@Tabrizu.ac.ir تلفن تماس: 9. 
يايه و اساس ساير عملكردهاى شناختى دخيل در خواندن است و بهعنوان

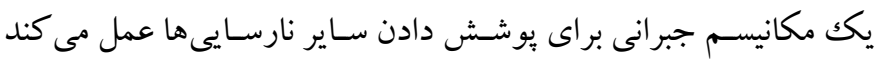

كنش هاى اجرايى در موفقيت تحصيلى و رشد اجتماعى نقش كليدى

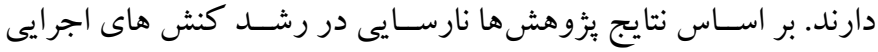

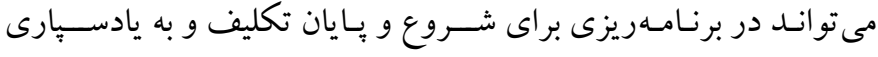

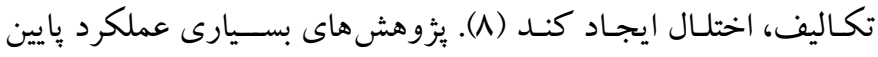

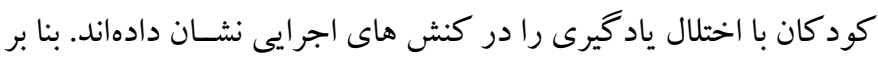
نظر داوسـون و گوئر كنشهاى اجرايى كمكك مى كنند تا نظمدهى رفتار از طريق به كار گيرى كنش هاى شناختى ويزه و تنظيم و هدايت آنها انجام

كيرد (9)

وجود نـارسـايى در كنشهـاى اجر ايى كودكـان با اختلال يادگيرى

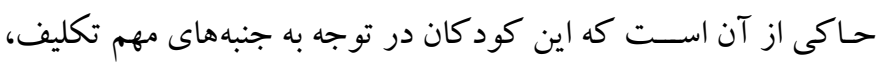

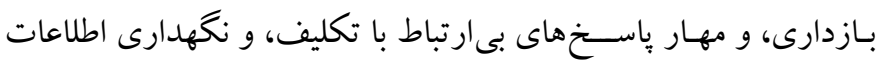

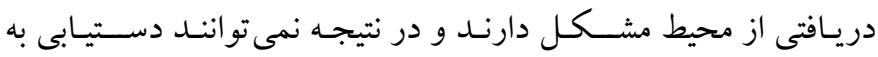
تقويت كننده را به تأخير بيندازند و به شيوههاى تكليفمدار به انجام دادن

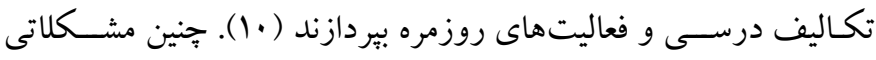

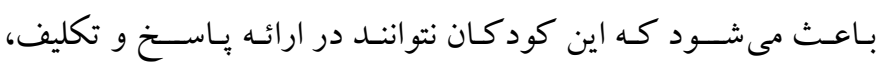

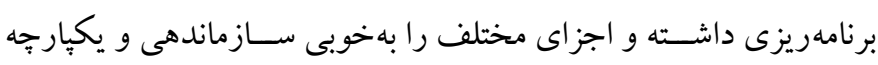

از آنجا كه خواندن بايه همه انواع ياد گيرى اســت، شـكســت در

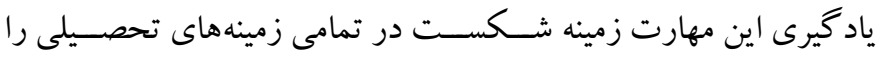

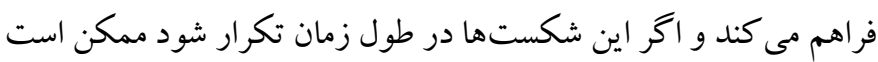

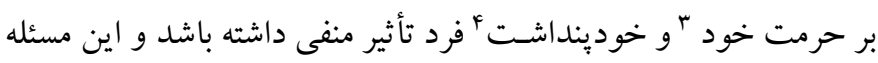

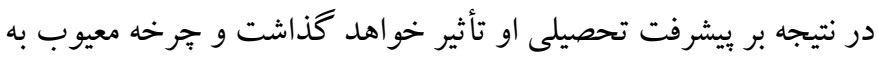

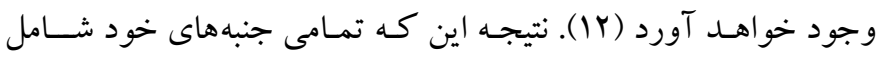

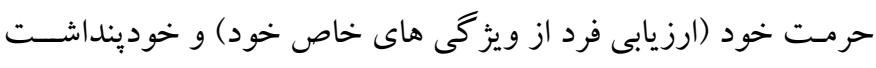

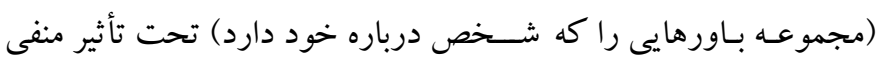

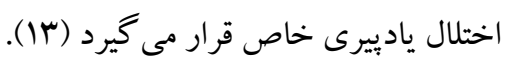

3. Self Steem

4. Self Concept
مقلدمه

خو اندن يكى از عمدهترين روشهاى كسـبـ دانش بهحســاب مى آيد. دانش آموزانى كه در خواندن ضعيف هستند در ياد گيرى دروس مختلف در تمامى سـالهاى تحصسيلى و بعد از آن آسـيب يذيرى بسـيارى نشـان

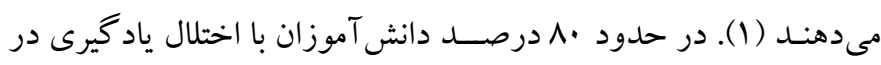
خواندن مشـكل دارند. كود كان با اختلال يادگيرى خواندن ممكن اسـت وازههاى بسـيارى را بدانند و در كفتار خود استفاده كنند اما در دركك و

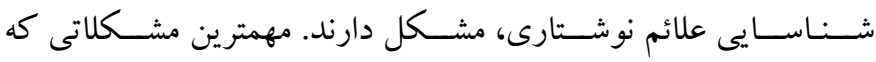
دانش آموزان با اختلال ياد گيرى خواندن تجربه مى كنند شــامل نارسـايى تهـي در خوانــن وازٔهــاى شــيـهـ به هم، حدس زدن وازمها با در نظر كرفتن حروف ابتدا و انتهاى آنها، وارونهخوانى وازهها، مشكلات شديد در هجى كردن، بىميلى و انزجار از يادگيرى، و دشوارى در تشخيص جزء از كل

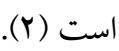

ميز ان شيوع اختلال خواندن در سنين 4 تا • ا ساله، با درصد است و يسران و/ إندصد بيشتر از دختران به اين اختلال مبتلا هستند. در اين زمينه بهرداد (INAF) بـا بررسـى نتـايج يزوهش هـاى انجـام يافته در ايران نرخ شيوع كلى را //ه درصد گزارش كرده است ولى نتيجه گر فتند كه ميزان ابتلا در پيسران // ا تا Y/Y درصد بيش از دختران است (Y). يُؤوهش هـا نشــان دادهانـد كه توانايى خواندن با كنش هاى اجرايى' رابطه تنگاتنگى دارد (r). اصــلاح كنشهاى اجرايى به ســازهاى كلى اشــاره دارد كـه شــامـل مهـارتهـاى گوناخونى مانند تصــميم گيرى، برنامهريزى، بازدارى، و سـازماندهى است و به فعاليت هاى شناختى عالى مغز مثـل توجـه، حافظهُ فعال'، زبان، ادراكك، و تفكر خلاق نياز دارد. اين كنشهـا در انجـام تكـاليف يادگيرى، عملكردهاى ذهنى، و فعاليتهاى تحصسيلى به افر اد كمكك مى كنند (F). برخى يزوهشها نشـان دادهاند كه تو انايى كود كان بيشدبسـتانى در مهارتهاى حافظه فعال مى تو اند سطح عملكرد خوانـدن آنها را در شـش ســال بعـد (ه) و يـا حتى در دوران بزر گسـالى (4) ييشبينى كند. سـو انسون در يكك يثزوهش فر اتحليل روى

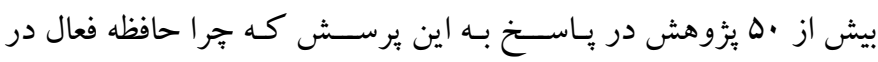
مشـكلات خواندن نقش دارد به اين نتيجه رسـيد كه حافظه فعال كلامى،

1. Excutive Function

2. Active Memory 
شـامل ينج مؤلفه اصلى اسـت كه مؤلفه كليدى آن بازدارى باسخ است.

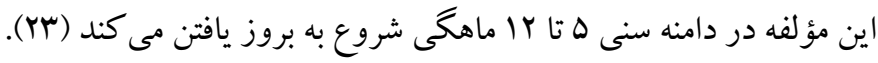

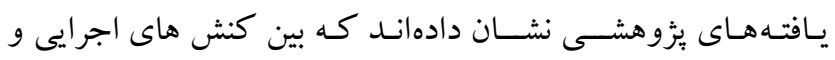

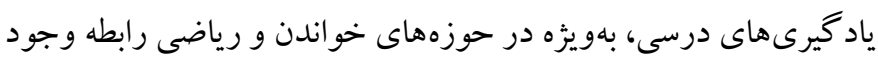

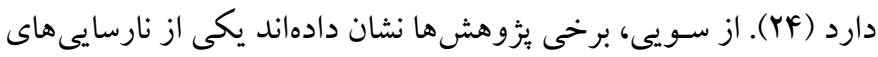

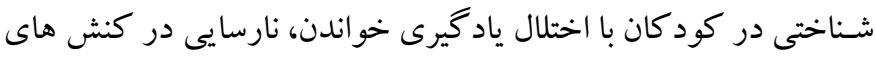

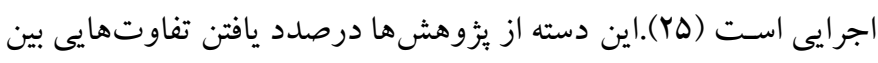

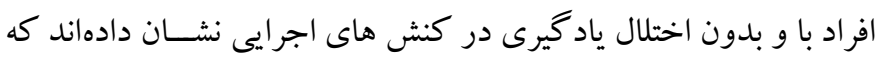

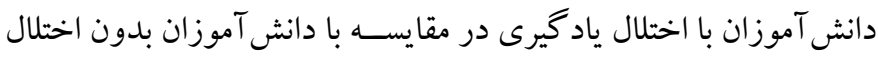
در حوزههاى مختلف كنش هاى اجرايى از قبيل حافظه فعال، برنامهريزى

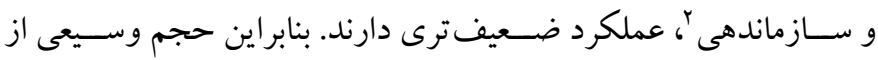
يافتهاى يزووهشى ، ضعف در كنش هاى اجر ايى دانش آموزان با اختلال

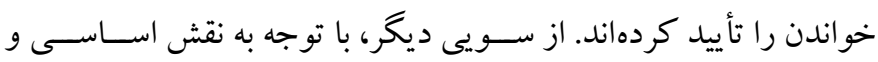

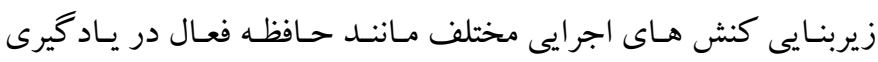
مهارت خو اندن، فرض مىشـود كه با تقويت و رشــــ كنشهاى اجر ايى

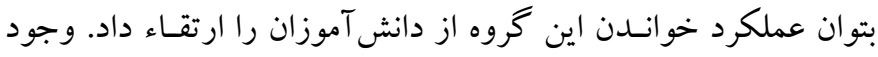
نقص در كنش اجرايى اين كود كان حاكى از آن اسـت كه اين كود كان

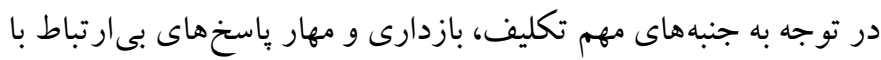

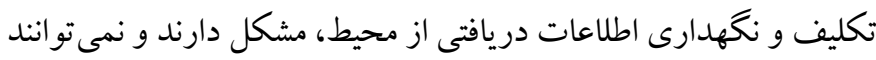

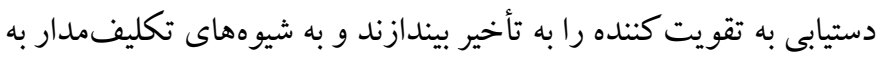

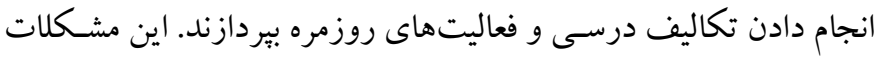

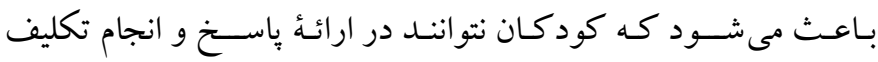

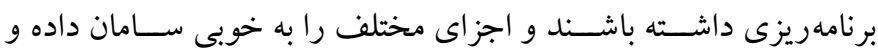

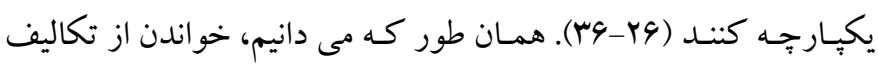
بسيار دشوارى است كه كود كان براى داشتن عملكرد مناسب در آن بايد از سطح بهينة توانايىهاى مورد اشـاره برخوردار باشند. با توجه به موارد

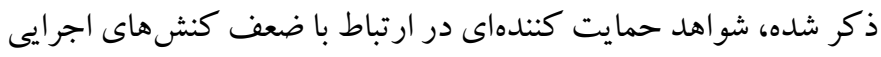

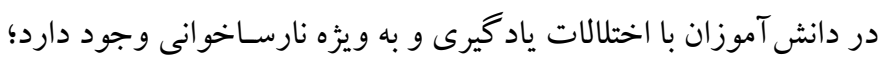

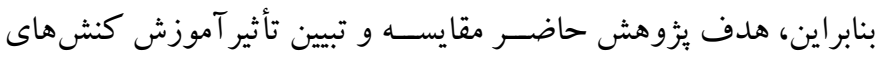

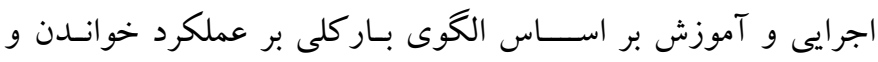

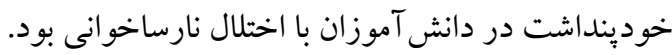

2. Organization
در حالى كه جنبه هاى شــناختى دخيل در فرايند خواندن، براى مدت

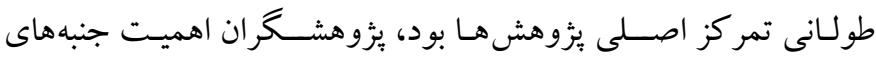

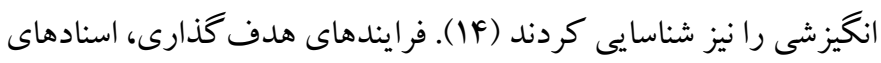

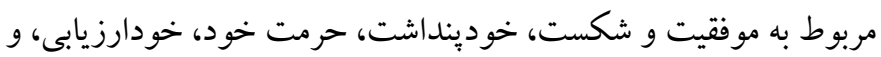

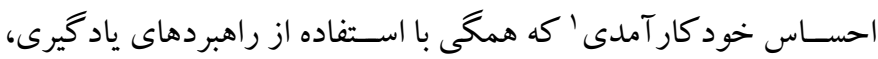

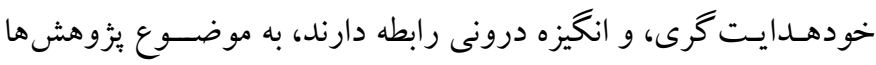

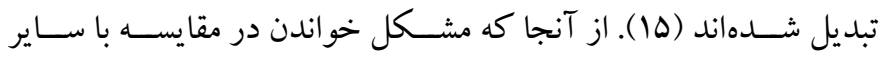

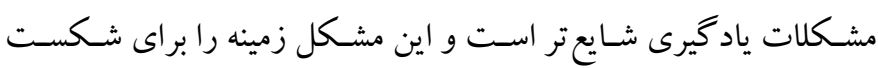

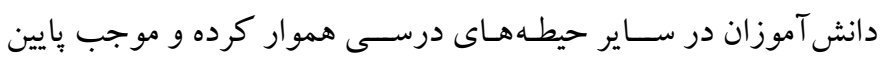

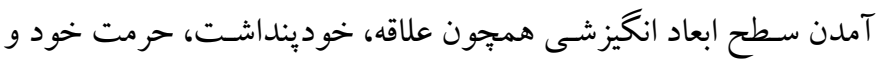

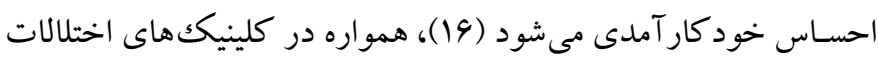

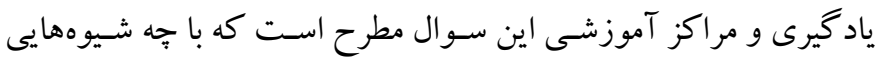

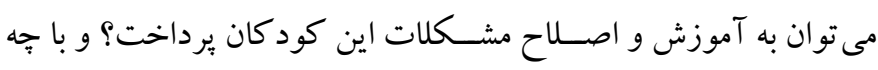
روشهايى مى توان سطوح انخيزشى آنها را نسبت به مواد آموزشى بالا

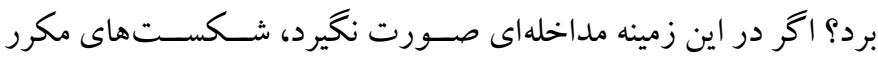
احساس ارزش شخصى دانش آموز را كاهش داده و موجب ايجاد تصور منفى از خويشتن مى شود و حرمت خود و خودينداشت فرد رد را خدشهد ردار

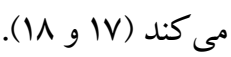

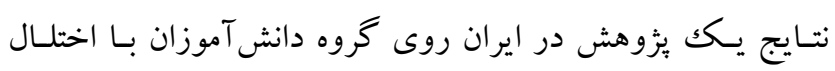

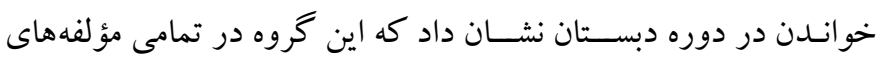

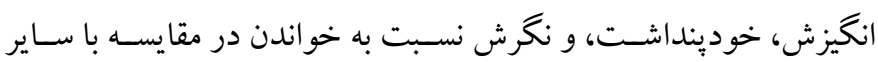

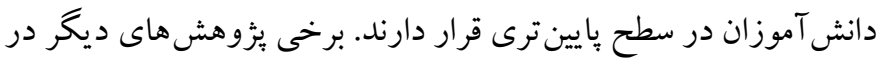

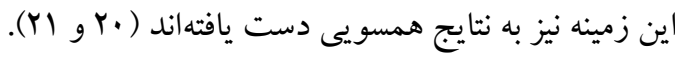

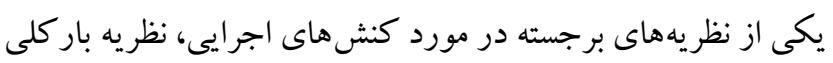

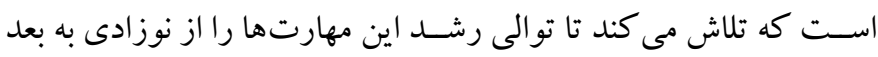

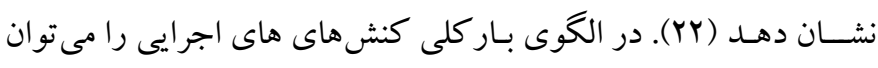

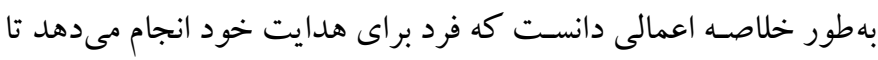

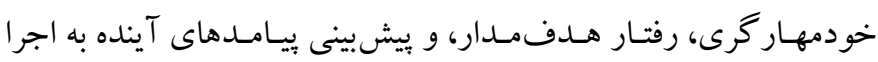

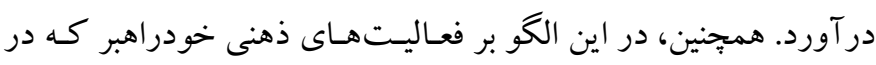

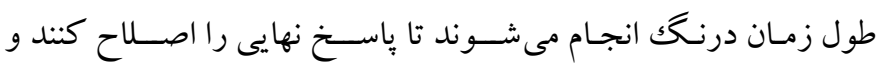

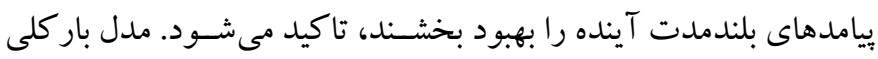


شد و از طريق مقايسه و ضريب همبستخى با برسشنامه هاى همتا، مطلوب

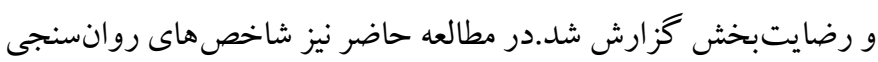

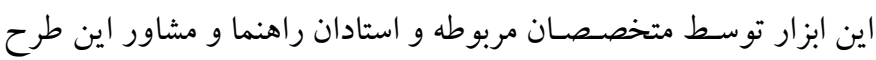
مورد تأييد قرار گرفت

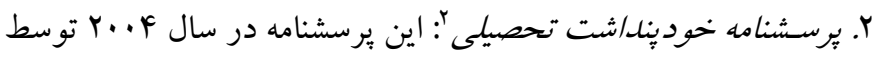

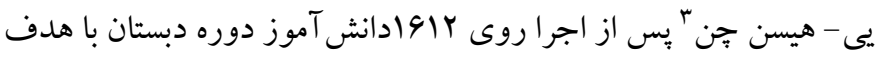

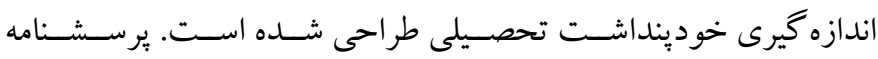

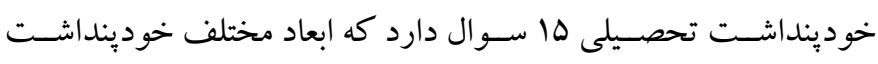

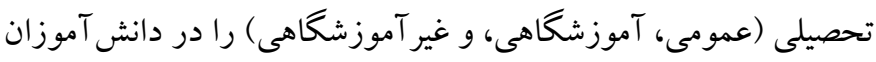

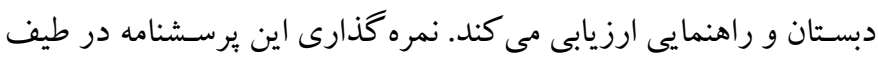
ينج درجهاى ليكرت انجام مىشـود. اين برسـشــامه توسـط مرعشسيان و

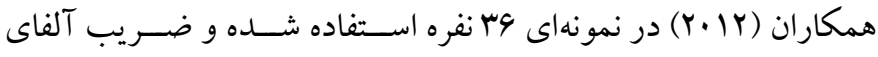

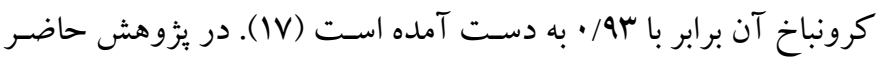

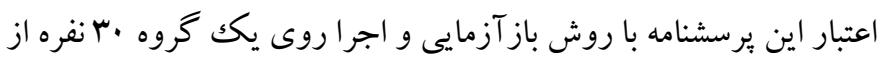

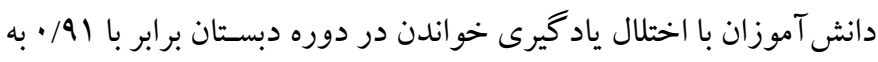

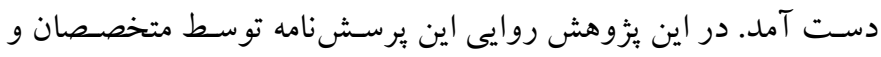
استادان راهنما و مشاور مورد تأييد قرار گرفته است.

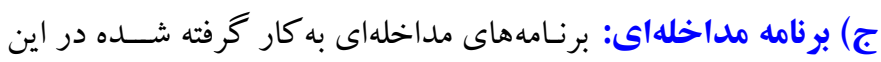

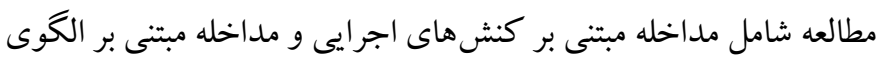

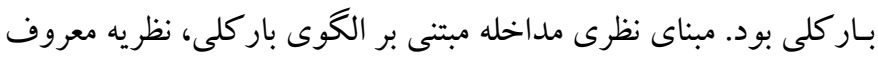

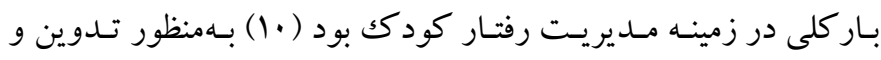

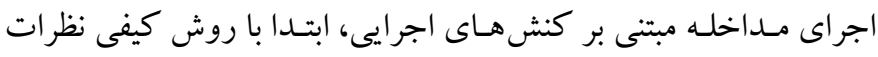

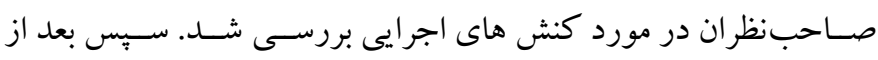

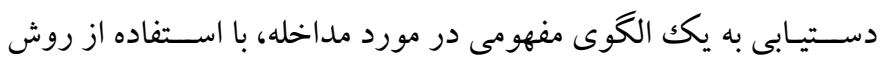

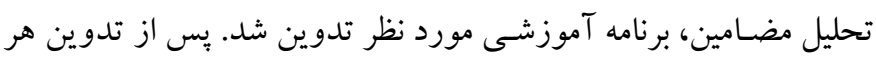

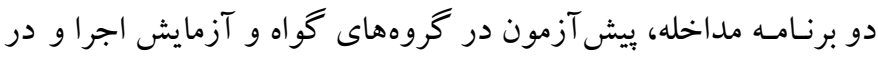

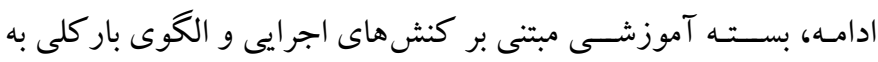

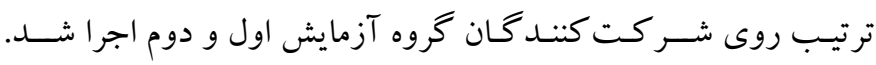
خلاصهاى از برنامههاى مداخلهاى در جدول إخزارش شئ شده است.
روش الف) طرح يزوهش و شـر كت كنند عان: يُزوهش حاضر نيمه آزمايشى

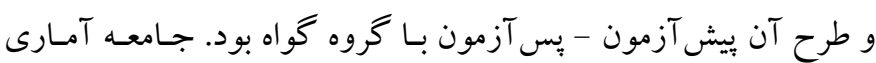

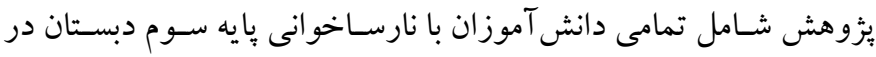

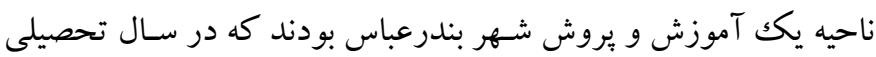

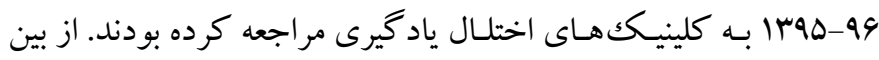

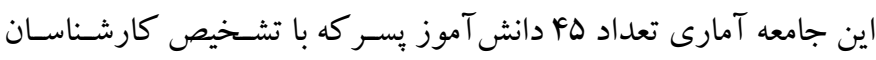

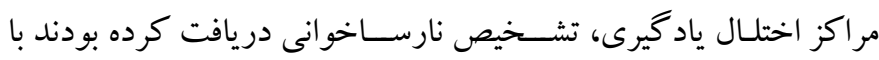

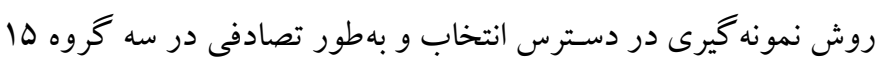

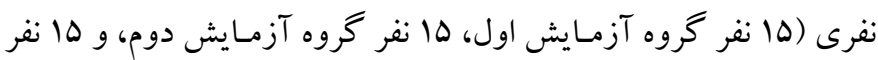

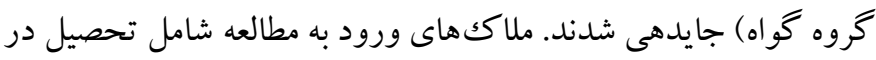
يايه سوم دبسـتان، دريافت تشـخيص اختلال نارسـاخو انى، رضايت ورود

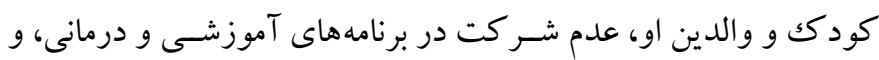
برخوردارى از دامنه هوشسى بهنجار بودند. ملاككهاى خروج شـامل عدم

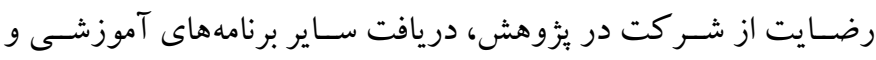

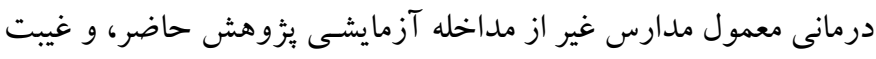

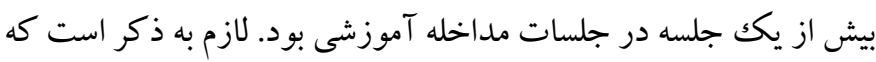

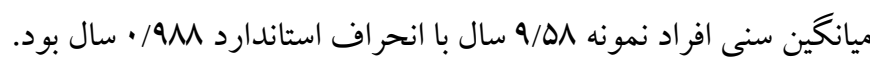

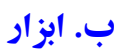
ا.برسشنامه عملكرد خواندن ': اين برسشنامه در سال هوسا توسط عابدى

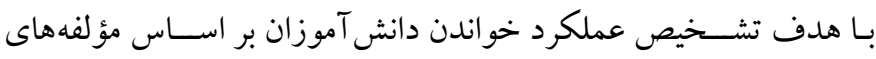

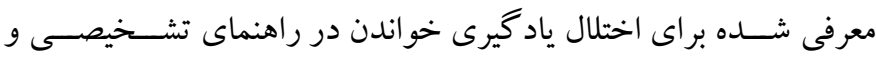
آمارى اختلال هاى روانى طراحى شده است. اين يرسشنامه باسو برال دارد

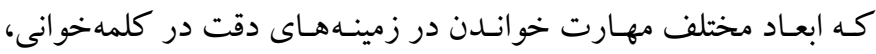

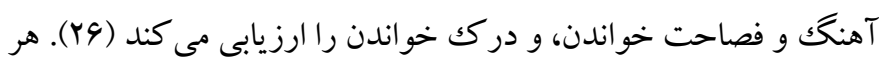

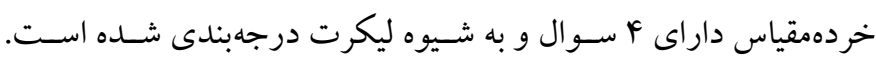

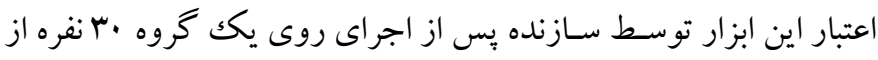

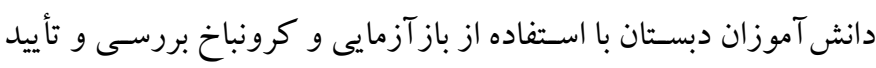

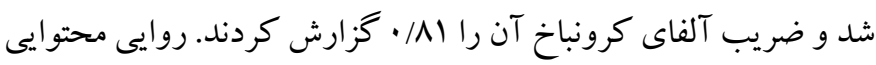

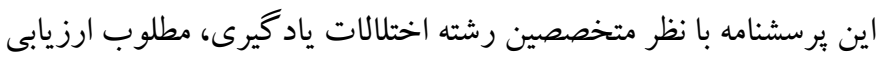




\section{جدول ا: جارجوب كلى جلسات مداخله كنث هاى اجرايى و مداخله مبتنى بر الكوى بار كلى}

\begin{tabular}{|c|c|c|}
\hline محتوا & محتوا & جلسه \\
\hline جلسات مبتنى بر الكوى بار كلى & جلسات مبتى بر كنشهاى اجرايى & \\
\hline 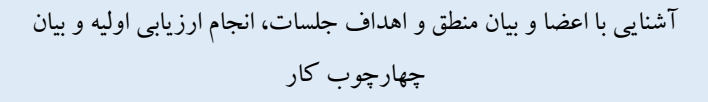 & آشنايى با اعضا و بيان منطق و اهداف جلسات، انجام ارزيابى اوليه و بيان جهارجوب كار & 1 \\
\hline آموزش توجه مثبت كود كث به تكاليف و احساس مسئوليتيذيرى نسبت به & موضوع عملكرد خو اندن (مشخص كردن هدف متن، محيط مناسب مطالعه، تمر كز و توجه در حين & r \\
\hline آموزش مهارت حل مساله و مراحل آن & آموزش فنون تصوير سازى ذهنى، استفاده از واسطهها و روش مكانها، يادداشتبردارى، خلاصه كردن و & $r$ \\
\hline آموزش باورهاى معقول و نامعقول و تغيير انتظارات & آموزش راهبردهاى نظمدهى و خودتنظيمى & f \\
\hline $\begin{array}{c}\text { مديريت وضعيت تحصيلى و درسى كودكى (انتخاب معلم، توصيههاى درباره } \\
\text { برنامه درسى و..) }\end{array}$ & يرداختن به كنش هاى اجرايى و عملكرد تحصيلى & $\Delta$ \\
\hline 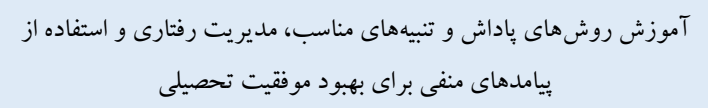 & 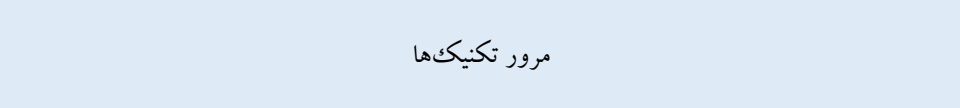 & 4 \\
\hline 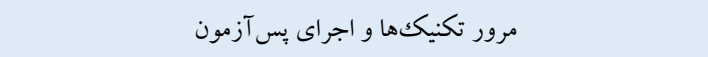 & 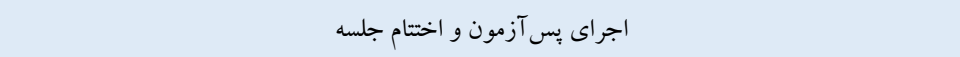 & v \\
\hline
\end{tabular}

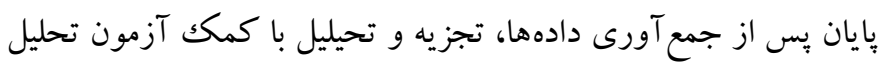
كوواريانس انجام شد.

\section{يافتهها}

اطلاعات توصيفى شامل ميانخين و انحراف معيار متغيرهاى خودينداشت

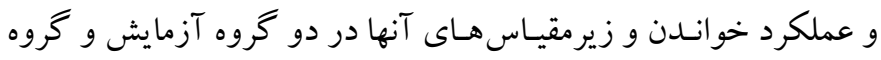

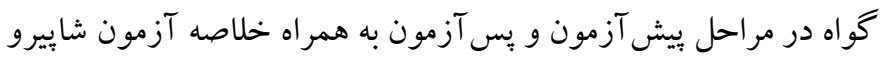
ويلكز براى تعيين نرمال بودن توزيع دادهها در جدول با ارائه شـده است. بـا توجـهـ بـهـ اين جدول نتايج آزمون شـــاييرو ويلكز بر براى تمامى متغيرها

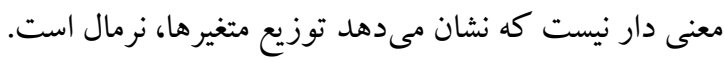

د) روش اجرا: بعد از خرفت مجوزهاى للازم جهت اجراى اين يُزوهش، افراد نمونه برحسب شرايط ورود و خروج، دريافت رضايتنامه و ساير براي

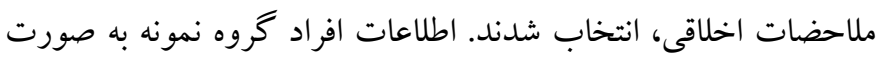
كد در نرمافزار ثبت شد و به آنها اطمينان داده شد دادهها به صورت اله

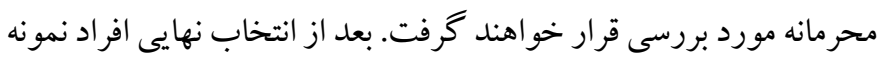

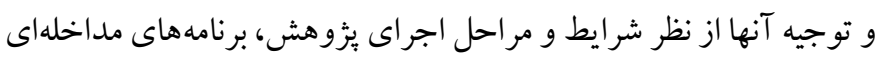

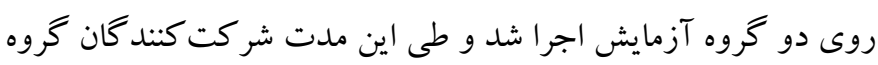

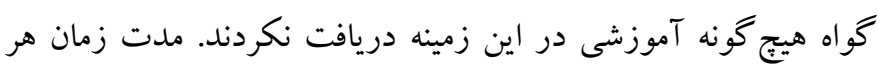

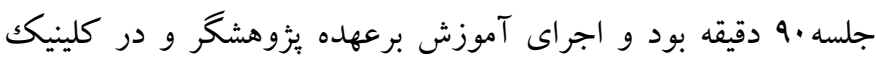

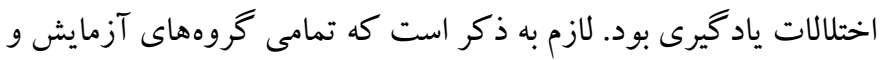

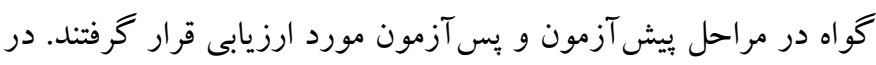

جدول r: شاخص هاى مركزى و يراكند

\begin{tabular}{|c|c|c|c|c|c|c|c|c|c|}
\hline \multicolumn{6}{|c|}{ يَسآزمون } & \multicolumn{2}{|c|}{ بيش آزمون } & \multirow{2}{*}{ كروه } & \multirow{2}{*}{ متغير } \\
\hline $\mathbf{P}$ & $\mathbf{W}$ & SD & $\mathbf{M}$ & $\mathbf{P}$ & $\mathbf{W}$ & SD & $\mathbf{M}$ & & \\
\hline . /AYD &.$/ 9 \vee \Delta$ & $F /$ Tr & IN/Ir & $\cdot /$ RYF &.$/ 941$ & $1 / 94$ & $r q / \cdot \cdot$ & بار كلى & \\
\hline$\cdot / \cdot v$ & $\cdot / 199$ & $F / F$. & $|F /| r$ & . &.$/ 94 A$ & $1 / \Delta$ & YN/AV & كنش اجرايى & نمره كل عملكرد خواندن \\
\hline$\cdot / T V Y$ & . /949 & $r / 9 Y$ & $r q / T r$ &.$/ 9.9$ &.$/ 9 V Y$ & r/Ar & rN/AT & كواه & \\
\hline .1194 &.$/ 910$ & $1 / r Y$ & $G / Y V$ & - /rYS &.$/ 94$. & •/Ar & $Q / \mathcal{F V}$ & بار كلى ل & \\
\hline$\cdot / 1 \cdot v$ & ./1941 & $1 / 4 \pi$ & f/ar &.$/ \cdot \Delta V$ & - /AVQ & $\cdot / 94$ & $Q / F V$ & كنش اجرايى & دقت در كلمه خوانى \\
\hline ./IVD &.$/ 918$ & $1 / 11$ & $Q / F V$ & $\cdot 11 \cdot 1$ & ./А9४ & $1 / r 4$ & $9 / 9 \mathrm{~V}$ & كواه & \\
\hline.$/ 1 Y q$ &.$/ 9 \cdot 9$ & $1 / 91$ & r/Dr & .1 .4 & - /AVD & $1 / F V$ & $V / r$. & بار كلى & فصاحت خد اندن \\
\hline$\cdot / \mu F$. &.$/ 949$ & I/Vr & $\mathrm{r} / \mathrm{AV}$ &.$/ .9 V$ & $\cdot / 9 . \cdot$ & $1 / 41$ & $\checkmark$ & كنش اجرايى & \\
\hline
\end{tabular}




\begin{tabular}{|c|c|c|c|c|c|c|c|c|c|}
\hline$\cdot / \cdot \Delta 9$ & $\cdot / M \Lambda \Delta$ & $1 / \Delta 9$ & $V / F$. & .1 .4 & - /ANV & $1 / 4 F$ & V/MT & كواه & \\
\hline$\cdot / \mathrm{VVV}$ & $\cdot / 990$ & Y/AY & V/Tr & سחות. &.$/ 91$. & $1 / 1 V$ & IY/rT & بار كلى & \\
\hline .1941 &.$/ 909$ & $r / 19$ & D/T & .1 .94 & - MAY & $1 / \cdot 0$ & $\mid r / 4$. & كنش اجر ايى & درك خواندن \\
\hline$\cdot / 1 \cdot r$ & -/^९४ & $1 / 1 \wedge$ & $\mid Y / F V$ & . &.$/ 9 \cdot 1$ & l/Ar & $11 / 94$ & كو اه & \\
\hline$\cdot / \cdot \mathrm{Vq}$ & - /AQF & $\Lambda / V r$ & $F I / F V$ & • & . /QYYF & $\Delta / 9 T$ & $\mu \mathrm{M}$. & بار كلى & \\
\hline$\cdot / r V Y$ & . /qrq & $r / N Y$ & $F \Delta / \Delta r$ & $\cdot /|r|$ & $\cdot / 9 \cdot V$ & $f / r$ & $r \cdot / \cdot r$ & كنش اجرايى & نمره كل خودينداشت تحصيلى \\
\hline$\cdot / 1 \wedge \Delta$ &.$/ 919$ & $r / 90$ & rq/9T & $\cdot / r \cdot$. &.$/ Q Y 1$ & $r / q V$ & rq & كواه & \\
\hline$\cdot / \cdot \Delta 9$ & - /MAD & $r / F r$ & $\mid r / F V$ & .1 .4 & $\cdot / M V$ & r/YD & $I 1 / T V$ & بار كلى & \\
\hline . &.$/ 9 \cdot 9$ & $1 / 94$ & $10 / \cdot V$ & ./1ra & $\cdot / 9 \cdot 1$ & $1 / 91$ & $1 \cdot 19 \mathrm{~V}$ & كنش اجرايى & عمومى \\
\hline$\cdot / Y Y A$ & . /AYF & $1 / F \Delta$ & $9 / \Delta r$ & $.19 \cdot 1$ & $\cdot / 9 \Delta \Delta$ & $1 / V$ & 9 & كواه & \\
\hline.$/ 199$ &.$/ 919$ & $F / \Delta q$ & $r Y / F V$ & . / FFr & - /aFD & $r / 4 \Lambda$ & $19 / 4 V$ & 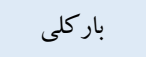 & \\
\hline.$/ 110$ & $\cdot / 9 \cdot \Delta$ & $1 / \wedge$. & $Y F / F V$ & | &.$/ 991$ & $r / \Delta r$ & $1 \Delta / \Delta r$ & كنش اجرايى & آموزشگاهى \\
\hline$\cdot / 9 \cdot 0$ & $\cdot / 9 \Delta \Delta$ & $r / M r$ & $\mid r / F V$ & $\cdot / r \cdot r$ &.$/ Q Y 1$ & $r / 49$ & سT/T & كواه & \\
\hline$\cdot / r \cdot V$ & . /QYr & $1 / 4$. & $\Delta / \Delta r$ & $\cdot / \cdot \wedge f$ & -/A9४ & $1 / Y \wedge$ & $r / \cdot v$ & بار كلى & \\
\hline$\cdot / Y F I$ & . AYr & - /AF & 4 & $\cdot / / V I$ &.$/ 918$ & $1 / 14$ & r & كنش اجرايى & غير آموزشگاهى \\
\hline$\cdot / r \mid 1$ & . 914 & 1/T & $r / 9 r$ &.$/ .94$ & . /1999 & $1 / \cdot 4$ & $r / 9 V$ & كو اه & \\
\hline
\end{tabular}

گ خروه ها برابر اسـت. آماره F تحليل كوواريانس بررسسى تفاوت گروهها

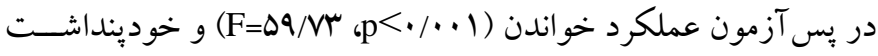

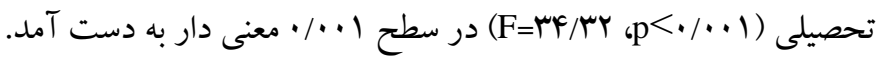
اين يافته ها نشـان مى دهند بين گرووهها در اين متغيرها تفاوت معنى دارى

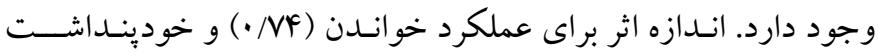

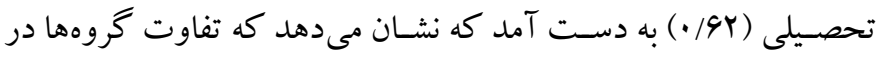

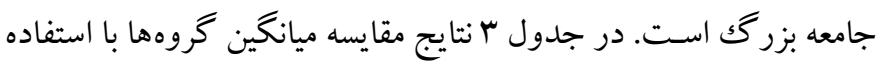

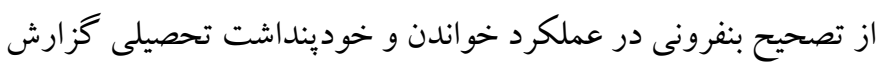
شده است.
براى بررسـى تـأثير آموزش كنشهـاى اجرايى و الكوى بار كلى بر

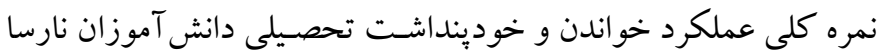

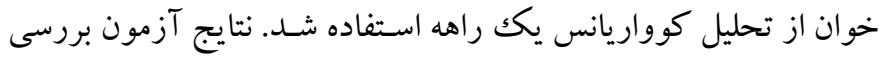

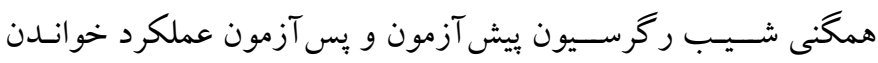

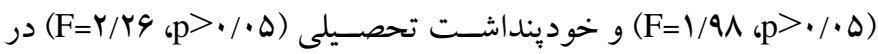

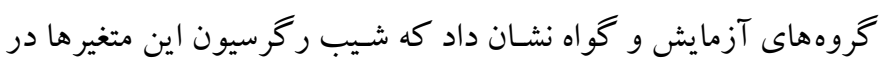

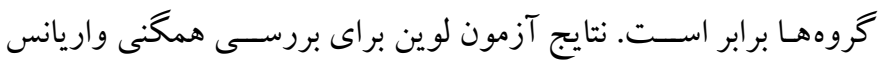

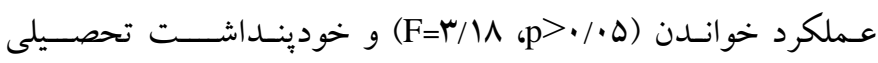

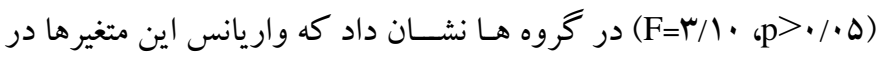

جدول r: نتايج مقايسه ميانكين كروهها در عملكرد خواندن و خودينداشت تحصيلى

\begin{tabular}{|c|c|c|c|c|c|}
\hline $\mathbf{p}$ & خطاى استاندارد & تفاوت ميانكين & كروه مقايسه & كروه مبنا & متغير \\
\hline.$/ \cdot r$ & $1 / F F$ & $r / q V$ & كنش اجرايى & بار كلى & عملكرد خواندن \\
\hline.$/ \cdot 1$ & $1 / F F$ & $-|1 / r|$ & كواه & بار كلى & \\
\hline$\cdot / \cdot 1$ & $1 / F F$ & $-10 / 11$ & كواه & كنش اجرايى & \\
\hline.$/ . F$ & $r / \cdot 1$ & $-F / F F$ & كنش اجرايى & بار كلى & خودينداشت تحصيلى \\
\hline.$/ \cdot 1$ & $r / Y \Lambda$ & $1 \% / 1 V$ & كواه & بار كلى & \\
\hline.$/ \cdot 1$ & $r / l F$ & $|V / 9|$ & كواه & كنش اجرايى & \\
\hline
\end{tabular}

( ) (p) و ميـانكين كروه بـار كلى و كنش اجرايى نيز بـه صـورت

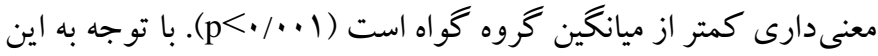

بـا توجسه بـه جـدول س، در عملكرد خوانسـن، ميـانخين كروه كنش اجرايى بـه صــورت معنى دارى كمتر از ميـانخين كروه بـار كلى اســت 
بررســى همكنى واريـانس مؤلفـهـهـاى عملكرد خو انـدن يعنى، دقت در

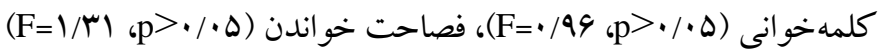

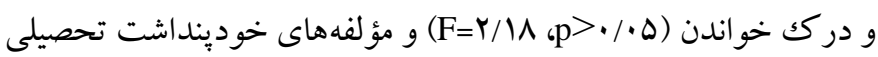

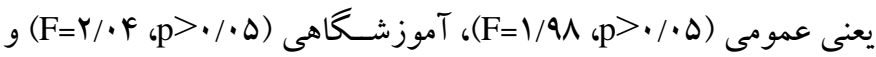

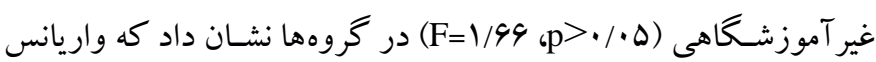
اين متغيرها برابر اسـت. نتايج آزمون باكس براى بررسى برابرى ماتريس كوواريانس متغيرهاى وابسته در بين گروه آزمايش و گواه نيز نشـان داد

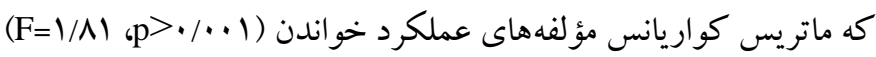

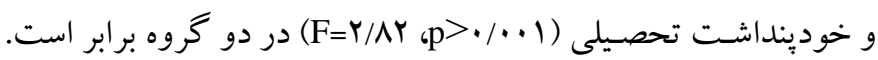
نتايج آزمون خىدو بارتلت براى بررسى كرويت يا معنى دارى رابطه بين

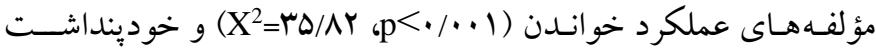

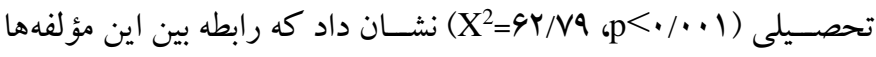
معنى دار است. نتايج تحليل كوواريانس جندمتغيرى نشان داد كه بين دو

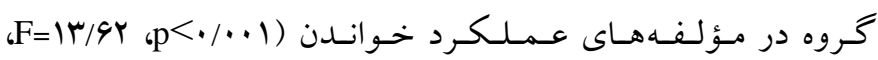

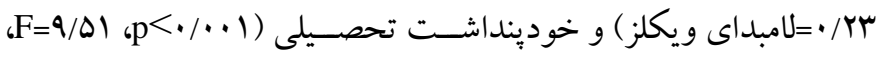
اس/•=لـامبداى ويكلز) تفاوت معنى دارى وجود دارد. براى بررسـى اين كـه گروههـاى آزمـايش و كواه در كـدام يـكك از مؤلفـهـهـاى عملكرد خواندن و خودينداشـت تحصـيلى با يكديخر تفاوت دارند در جدول F F نتايج تحليل واريانس تككمتغيرى گزارش شده است.
يـافتها مىتوان كفت كه آموزش كنش هاى اجر ايى و الكوى بار كلى بر عملكرد خواندن دانش آموزان نارساخوان تأثير مثبت دارد، اما تأثير روش كنش اجرايى بيشـتر از روش بار كلى اسـت. در خودينداشـت تحصسيلى، ميانگين كروه بار كلى و كنش اجرايى نيز به صسورت معنى دارى بيشتر از ميـانگين گروه كواه اسـت (1) ( p) و بين دو گروه باركلى و كنش

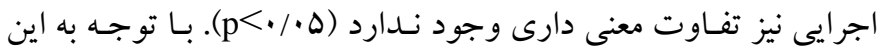
يـافتها مىتوان كفت كه آموزش كنش هاى اجرايى و الكوى بار كلى بر خودينداشـت تحصـيلى دانش آموزان نارسـا خوان تأثير مثبت دارد ولى روش مبتنى بر كنشهاى اجرايى تأثير معنادارترى دارد. براى بررسـى تأثير آموزش كنشهـاى اجرايى و الكوى بار كلى بر مؤلفـهـهـاى عملكرد خوانـدن و خودينـداشــت تحصـــلى دانش آموزان نارسـاخوان از تحليل كوواريانس جندمتغيرى اسـتفاده شـــ. نتايج آزمون بررسـى همكنى شــيب ركرســيون بيش آزمون و يس آزمون مؤلفههاى

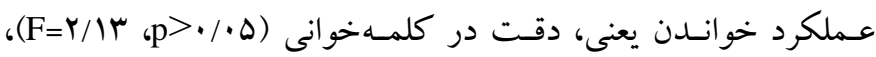

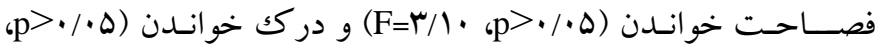

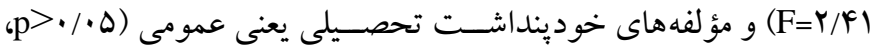

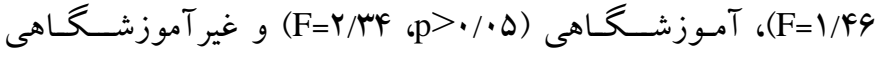

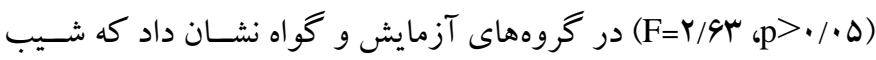
ركرســيون اين مؤلفهها در گروهها برابر اســت. نتايج آزمون لوين براى

جدول ع: نتايج تحليل واريانس يكرراهه تفاوت تروهها در مؤلفههاى عملكرد خواندن و خودينداشت تحصيلى

\begin{tabular}{|c|c|c|c|c|c|c|c|c|}
\hline اندازه اثر & $\mathbf{p}$ & $\mathbf{F}$ & خطا MS & كروه MS & خطا SS & SS & مؤلفه & متغير \\
\hline$\cdot / N 1$ & $\% / .1$ & FN/DV & $1 / \Delta V$ & VG/FF & $91 / T V$ & $10 r / \wedge q$ & دقت & \\
\hline.$/ 49$ & $\%$ & $I V / I T$ & $r / V r$ & FG/VA & $1.9 / 09$ & $Q T / \Delta Q$ & فصاحت & عملكرد خواندن \\
\hline .199 & $\% / \cdot 1$ & $\mathrm{Kr} / \mathrm{Ar}$ & $4 / 99$ & $r \cdot \Delta / 9 V$ & $\mid \Lambda r / \cdot r$ & $F \| / N \Delta$ & درك & \\
\hline$\cdot / k \mu$ & $\% \cdot \cdot 1$ & IF/VY & $\Delta / 9 F$ & $\Lambda \mu / T$ & $r r \cdot / 19$ & $199 / Y F$ & عمومى & \\
\hline .194 & $\% / \cdot 1$ & $r q / 1 r$ & $1 \cdot 109$ & HNI/VF & fIr/l. & $V G M / F A$ & آموزشگاهى & خودينداشت تحصيلى \\
\hline.$/ r q$ &.$/ .1$ & $\Lambda / \mu$ & $1 / \mu$. & 1./Ar & $0 . / V Y$ & $r I / 9 V$ & غير آموزشگاه & \\
\hline
\end{tabular}

كروههـا در اين مؤلفـههـا تفاوت معنى دار وجود دارد. در جدول ه نتايج مقايسـه ميانكين گروهها با اســتفاده از تصـسحيح بنفرونى در مؤلفه هاى عملكرد خواندن و خودينداشت تحصيلى گز ارش شده است.
با توجه به جدول F F آماره F براى مؤلفه هاى دقت (FN/DV)، فصاحت

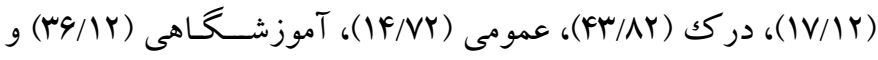

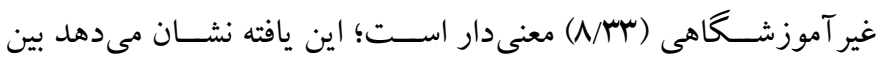


جدول 0: نتايج مقايسه ميانكين كروهها در مؤلفههاى عملكرد خواندن و خودينداشت تحصيلى

\begin{tabular}{|c|c|c|c|c|c|}
\hline $\mathbf{p}$ & خطاى استاندارد & تفاوت ميانغين & كروه مقايسه & كروه مبنا & مؤلفه \\
\hline$\% \Delta$ & $\cdot / 4 \Delta$ & $1 / \% \Delta$ & كنش اجرايى & باركلى & \\
\hline.$/ \cdot 1$ & $\cdot / 49$ & $-r / 19$ & كواه & بار كلى & دقت \\
\hline.$/ \cdot 1$ & $\cdot / q V$ & $-F / \Delta r$ & كواه & كنش اجرايى & \\
\hline 年 & .19. & .19 & كنش اجرايى & بار كلى & \\
\hline.$\cdot \cdot 1$ & .191 & $-r / \Lambda$. & كواه & بار كلى & فصاحت \\
\hline.$/ .1$ & .191 & $-r / F$. & كواه & كنش اجرايى & \\
\hline.$/ \cdot 1$ & $\cdot / \mathrm{Va}$ & $r / \cdot 1$ & كنش اجرايى & بار كلى & \\
\hline.$/ .1$ & $\cdot / \wedge$. & $-\Delta / r \Delta$ & كواه & بار كلى & درك \\
\hline.$\cdot \cdot 1$ & $\cdot / A \mid$ & $-V / r^{4}$ & كواه & كنش اجرايى & \\
\hline .1 .9 & $\cdot / A V$ & $-1 / V \Delta$ & كنش اجرايى & بار كلى & \\
\hline$\% r$ & $1 / \cdot 1$ & $V / \mu F$ & كواه & بار كلى & عمو مى \\
\hline.$/ \cdot 1$ &.$/ 94$ & $\Delta / 1$. & كواه & كنش اجرايى & \\
\hline.$/ .9$ & $1 / r$. & $-Y / I Y$ & كنش اجرايى & بار كلى & \\
\hline.$/ .1$ & $1 / T V$ & N/9. & كواه & بار كلى & آموزشكاهى \\
\hline.$\cdots 1$ & $1 / Y \Lambda$ & $1 \cdot / V r$ & كواه & كنش اجرايى & \\
\hline$\cdot / \cdot r$ & d / FT & $-\cdot / \Delta \Delta$ & كنش اجرايى & بار كلى & \\
\hline$\cdot / \cdot 1$ & $\cdot / 4 \lambda$ & $1 / Y \wedge$ & كواه & بار كلى & غير آموزشكاهـ \\
\hline.$/ .1$ & $\cdot / 4 \Delta$ & l/Ar & كواه & كنش اجرايى & \\
\hline
\end{tabular}

نارسـاخوان تأثير مثبت دارد ولى روش مبتى بر كنشهاى اجرايى، تأثير معنادارترى دارد.

\section{بحث و نتيجه كيرى}

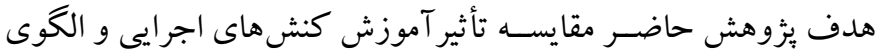
بار كلى بر عملكرد خو اندن و خودينداشــت تحصـيلى در دانش آموزان

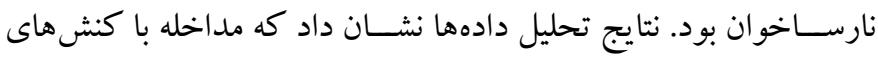

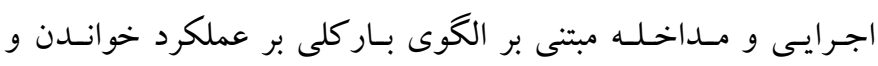

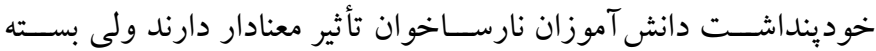

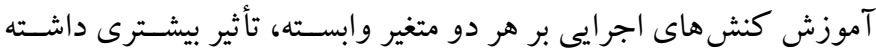

نتيجـه فرضـيه نخسـت اين مطالعه مبنى بر تأثير آموزش كنشهاى

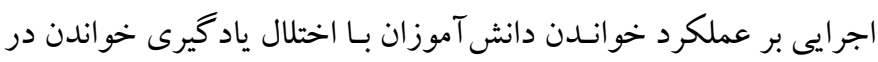
ئزوهش حاضسر با نتايج يزٔوهش هاى بيشـين از جمله (ه، 9، 9 و YV) كه

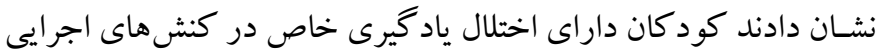

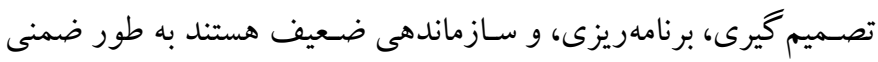

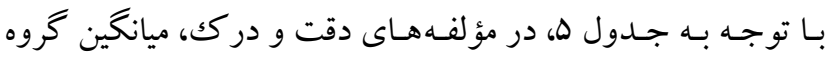

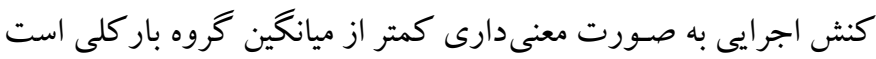

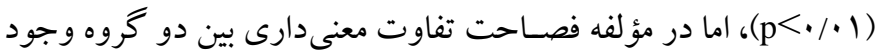

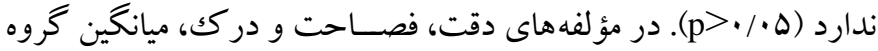
بار كلى و كنش اجرايى نيز به صـورت معنىدارى كمتر از ميانگين گروه

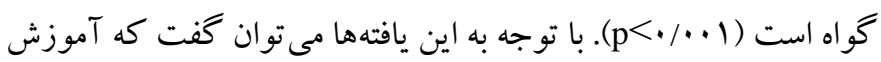

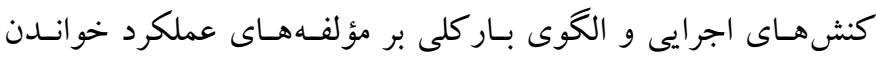

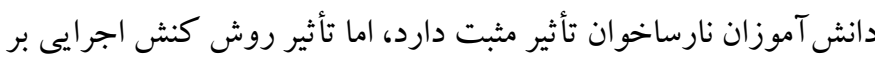
مؤلفـهـهـاى دقت و درك بيشــتر از روش بار كلى اســت. در مؤلفههاى

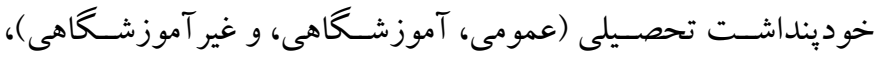

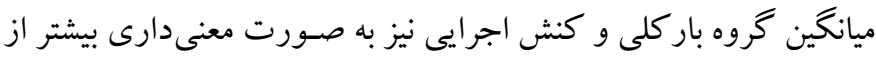

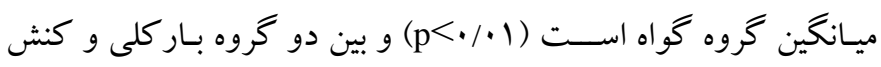

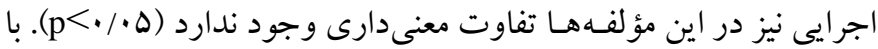

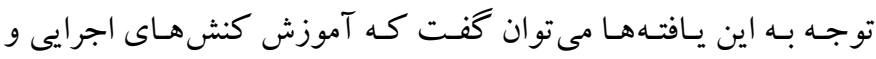

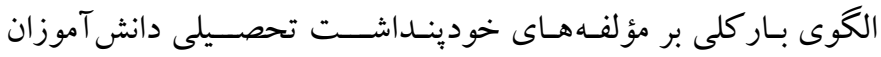


شـركت كننده در گروه آزمايش به آنها كمك كرده است تا با بهبود اين

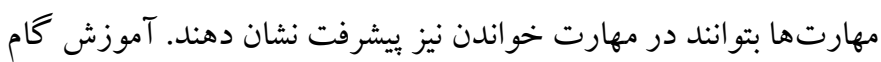

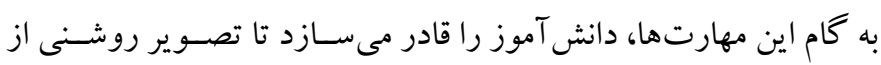

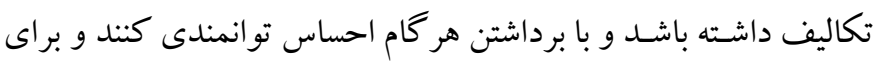
برداشتن كام بعدى انگيزه داشته باشد.

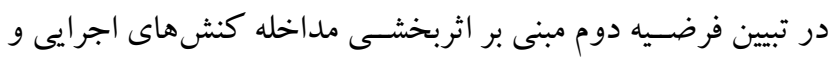

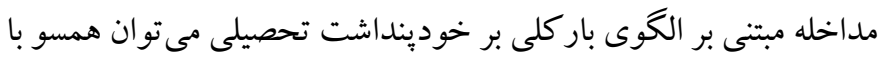

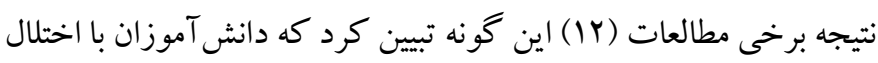

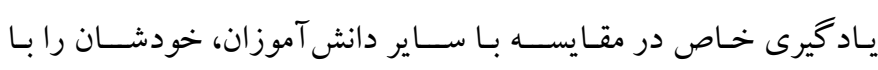
عبارت هاى منفى بيشترى توصيف مى كنند و شكست هاى تحصيلى شان

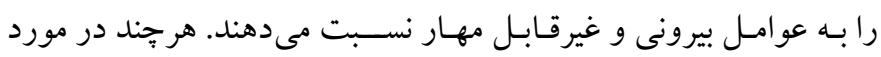

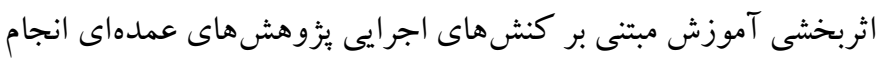

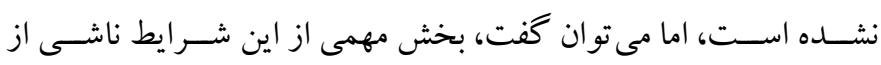

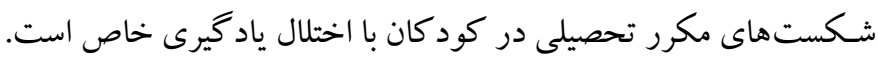

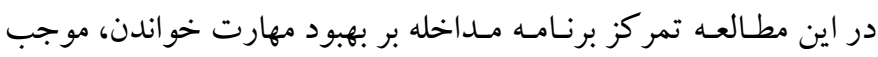

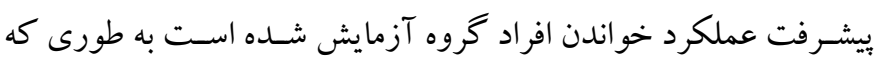

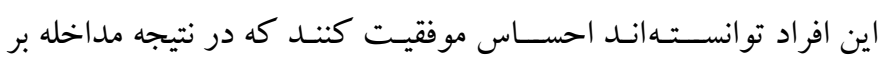
خودينداشـت تحصسيلى آنها اثر مثبت گذاشـته اسـت. در اين زمينه نتايج

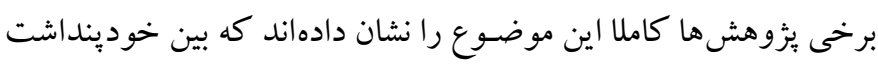

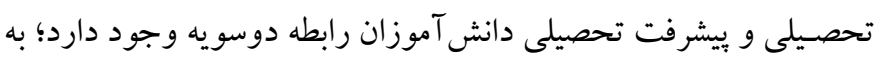

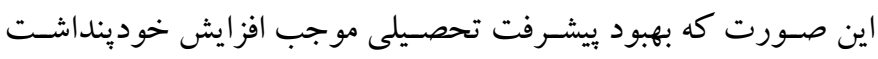

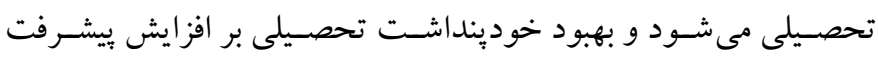

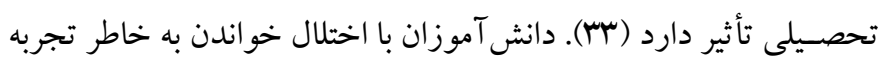

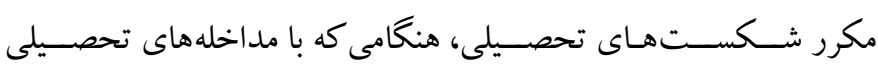

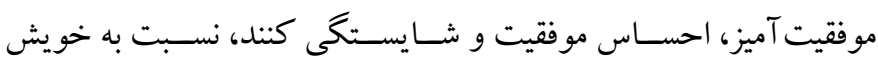

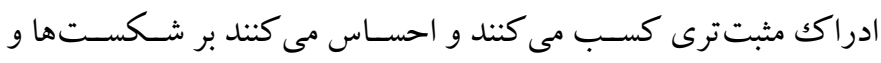

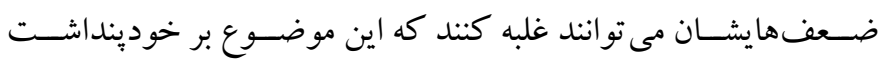
تحصيلى آنها تأثير مثبت خواهد داشت نوانت عليه

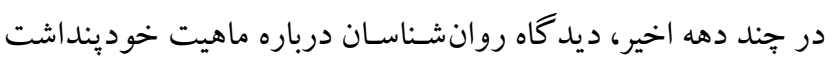

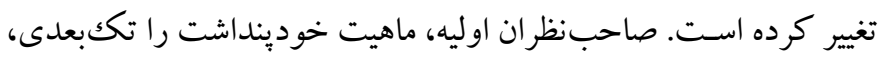
واحد و ثابت فرض مى كردند، درحالى كه صـاحبنظر ان معاصـر اعتقاد

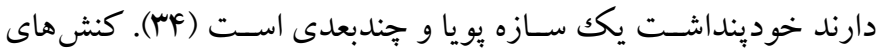

همسو است. هولمز و همكاران در يثزوهش خود نشان دادند كه عملكرد مغزى مرتبط بـا كنش هـاى اجرايى (حسافظه فعـال) در كود كـان يس از

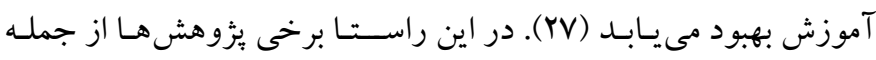

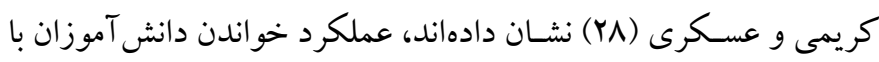

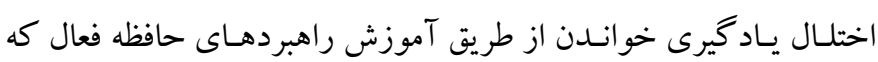

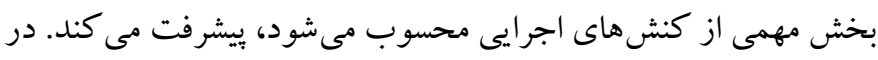

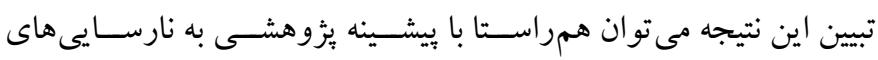

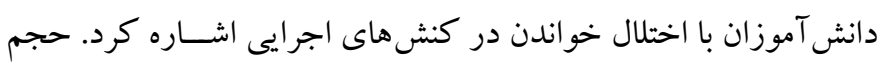

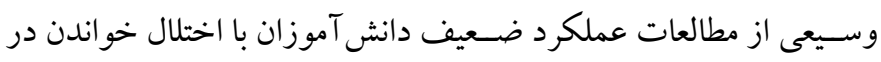

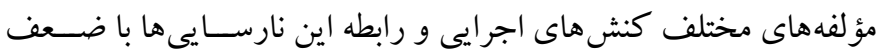

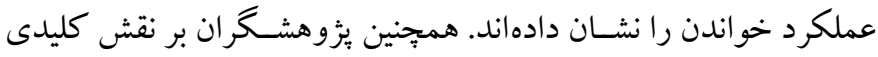
كنشهـاى اجر ايى در يـاد گيرى مهارتهاى تحصـيلى، بهويزه مهارت

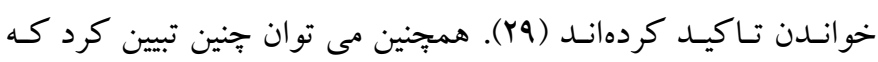

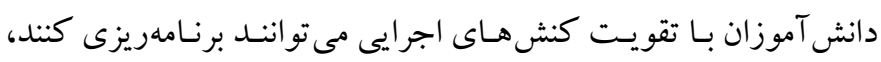

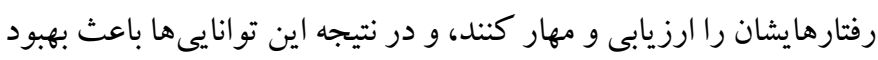

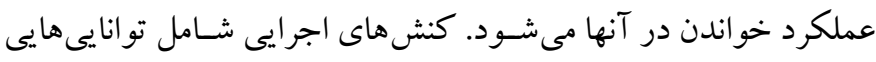

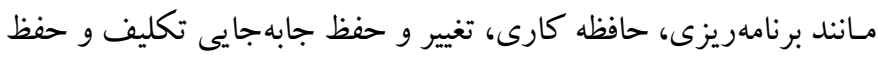

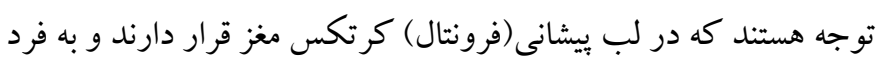

توانايى مهار گرى و انعطاف يذيرى در تكاليف را مى دهند (ب).

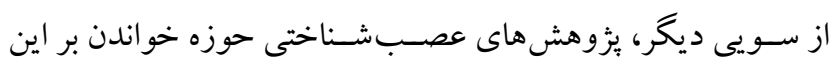

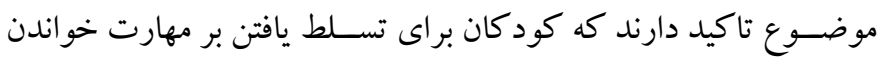

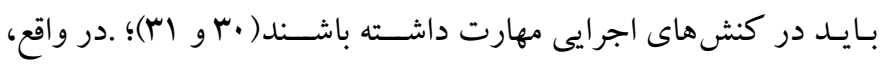

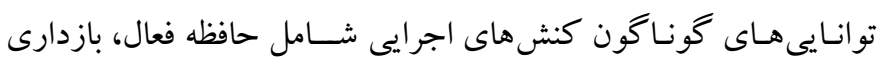

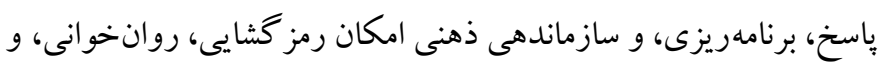

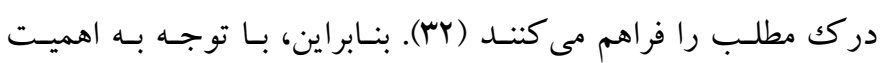

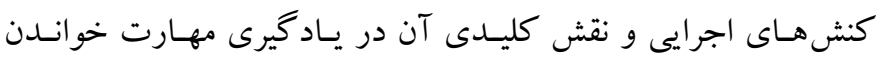

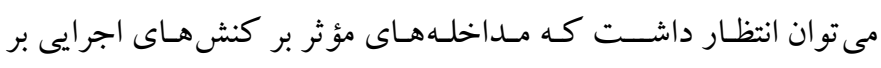

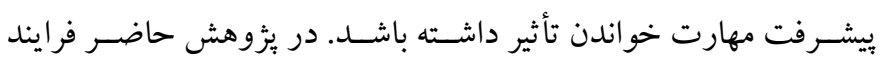

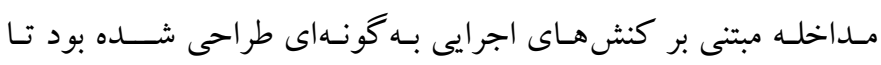

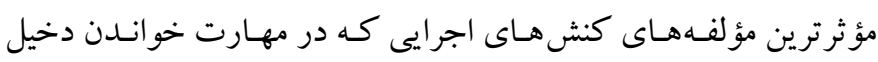

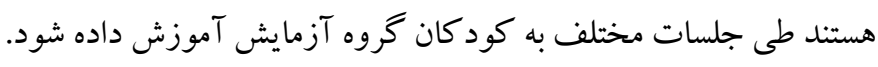
آموزش كنشهـاى اجر ايى مؤثر در مهـارت خوانسدن بـه دانش آموزان 
دانش آموز، بيشـتر مى كند. در اين زمينه، درمانكر ان و متخصصان بالينى

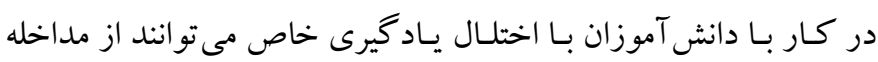

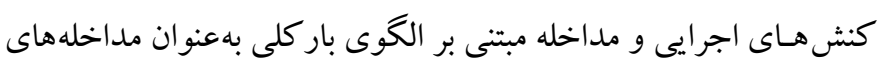

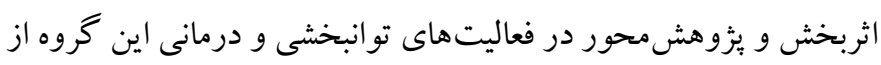

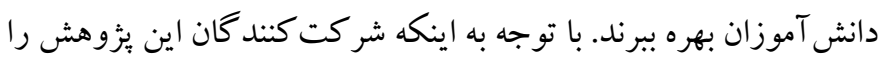

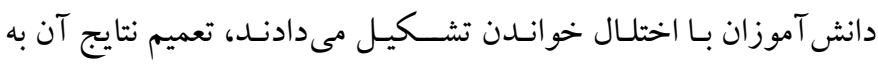

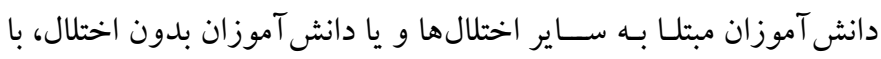

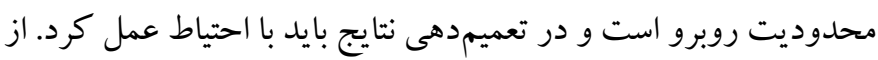

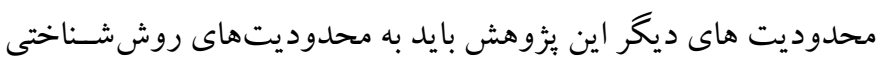

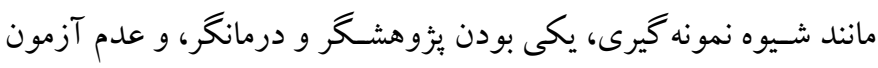

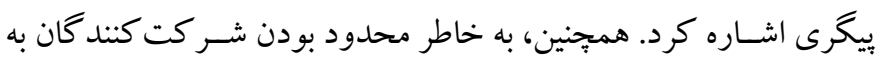

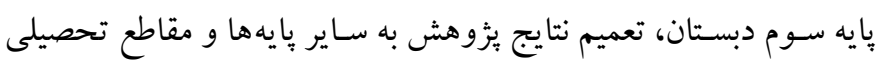

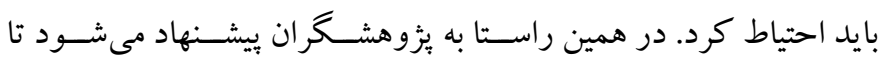
اثربخشى مداخله كنشهاى اجرايى و الكوى بار كلى را در دانش آموزان

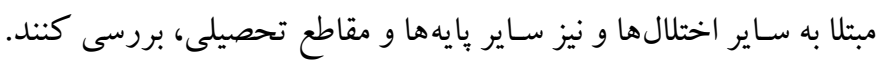

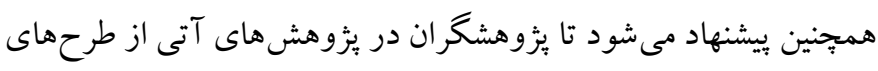

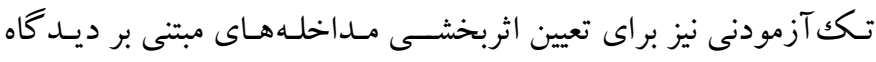

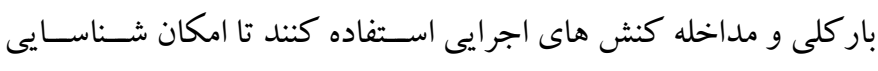

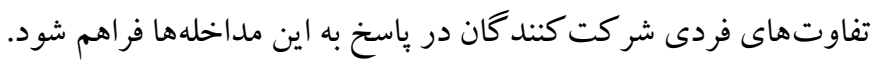

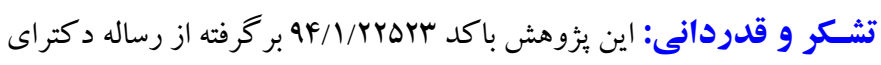

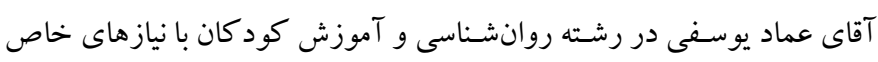

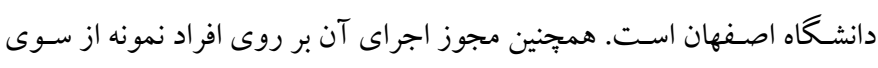

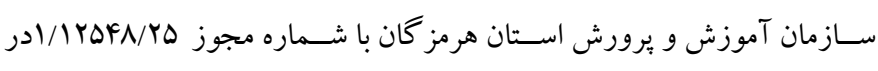

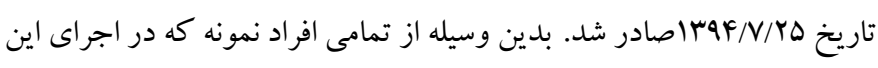

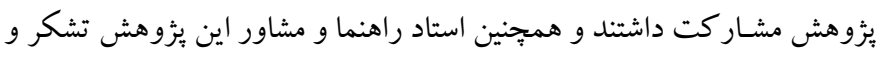
قدردانى مى شود. تضـاد منافع: انجام اين يُزوهش براى نويسند كان هيج گونه تضاد منافع نداشته
اجرايى از طريق مهار و تنظيم رفتارهاى ار ادى و هدفمند باعث مىشـوند

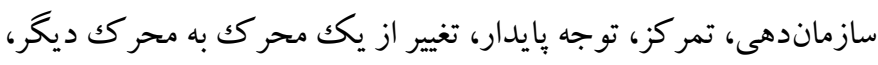

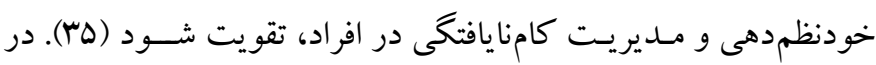
واقع دانش آموزان با ياد گيرى و به كار گيرى كنش هاى اجر ايى از تكانشى دونى

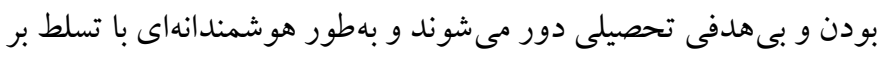

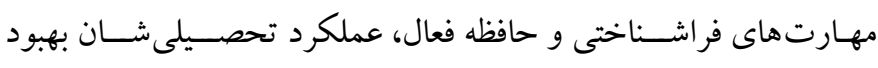
مى يابد. اثربخشــى مداخله كنش هاى اجر ايى در مقايســه با مداخله مبتنى بر

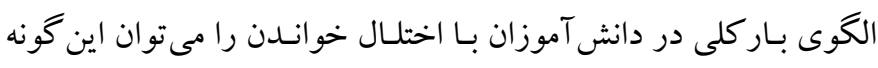

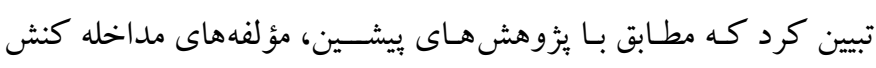

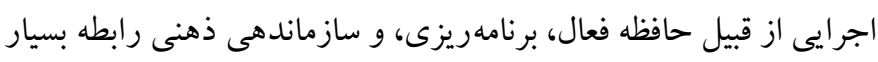

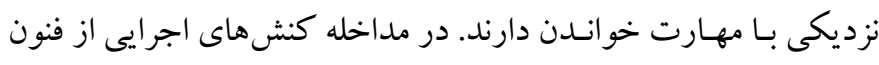

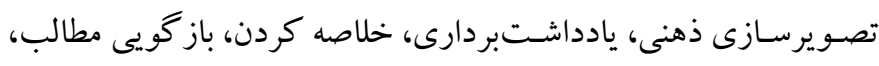

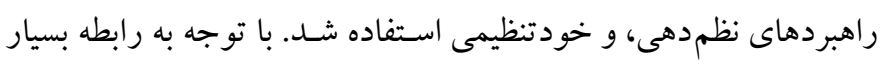

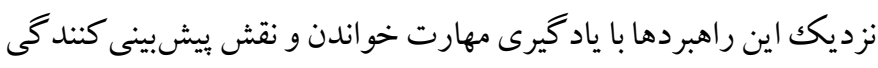

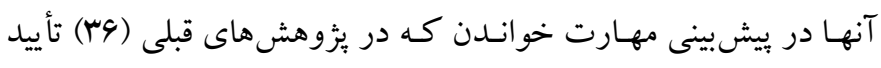
شـده است مى توان انتظار داشت كه استفاده از اين تكنيككها و راهبردها

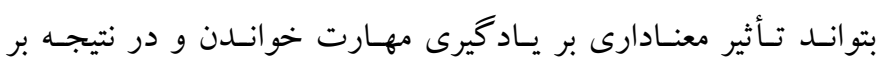
خودينداشت دانش آموزان داشته باشند. نتايج يثزوه حاضسر مبنى بر اثربخشى مداخله كنشهاى اجرايى و

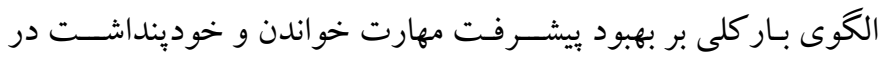

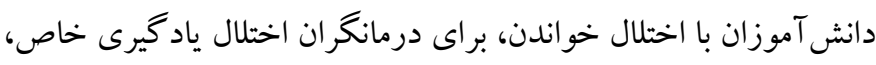

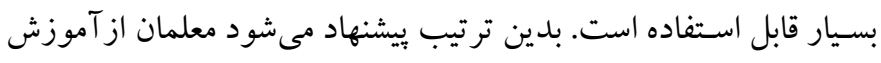

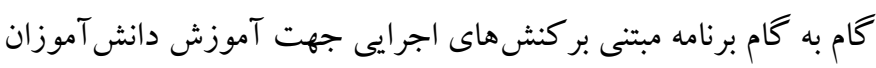

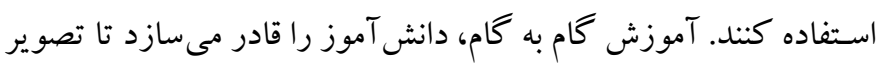

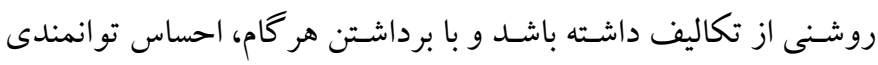

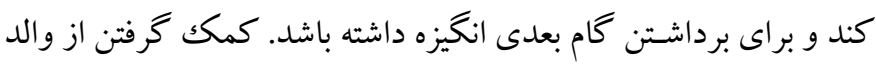

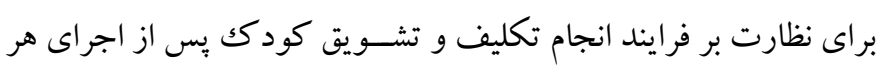

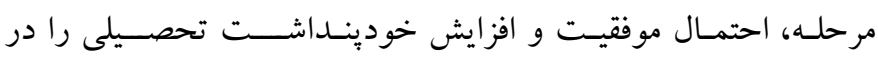




\section{References}

1. Maughan B, Messer J, Collishaw S, Pickles A, Snowling M, Yule W, Rutter M. Persistence of literacy problems: spelling in adolescence and at mid-life. Journal of Child Psychology and Psychiatry. 2009; 50 (8):893-901. [Link]

2. Brooks AD, Berninger VW, and Abbott RD. Letter naming and letter writing reversals in children with dyslexia: Momentary inefficiency in the phonological and orthographic loops of working memory. Developmental neuropsychology. 2011 Oct1;36(7):847-68 . [Link]

3. Hoskyn, M. J, Iarocci, G, Young, AR. Executive functions in children's everyday lives: A handbook for professionals in applied psychology. Oxford University Press. 2017; 217-240. [Link]

4. Hoskyn MJ, Iarocci G, Young AR, editors. Executive functions in children's everyday lives: A handbook for professionals in applied psychology. Oxford University Press; 2017. [Link]

5. Schuchardt K, Maehler C, Hasselhorn M. Working memory deficits in children with specific learning disorders. Journal of Learning Disabilities. 2008 ; 41 (6): 514-23. [Link]

6. Smith-Spark JH, Fisk JE. Working memory functioning in developmental dyslexia. Memory. 2007 1;15(1):34-56. [Link]

7. Swanson HL. Adults with reading disabilities: Converting a meta-analysis to practice. Journal of Learning disabilities.2012;45(1):17-30. [Link]

8. Barclay, Russell. Educating children with a high level of attention deficit hyperactivity disorder (ADHD), Ahmad Abedi and Adleh Sharbafzadeh (trans.) Isfahan Kavoshar Publications. 2015; 110-115. [Persian]. [Link]

9. Dawson P, Guare R. Executive skills in children and adolescents: A practical guide to assessment and intervention. Guilford Publications; 2018, 13. [Link]

10. Dawson, $\mathrm{P}$, Guerre, R. Executive functions in children and adolescents: A guide to assessment and intervention. Ali Akbar Ebrahimi, Ahmad Abedi, Salar Faramarzi, Bita Achaee \& Munir Behrouz (trans.) Isfahan: Neveshteh Publication. 2014; 75-90. [Link]

11. Alloway TP, Wootan S, Deane P. Investigating working memory and sustained attention in dyslexic adults. International Journal of Educational Research. 2014;67: 11-7. [Link]

12. Karimi, Yousef. Learning disorders: Theoretical and practical issues. Tehran: Savalan Publication. 2008; 55-63. [Persian]. [Link]
13. Seif, A. Ak. Modern psychology: Psychology of learning and education. Tehran: Dowran Publication. 2007; 171-176. [Persian] [Link]

14. Pintrich, P. R. The role of goal orientation in selfregulated learning. In M. Boekaerts, P. R. Pintrich, \& M. Zeidner (Eds.) Handbook ofself-regulation. San Diego, CA: Academic Press; 2000; pp: 452-502. [Link]

15. Schunk, D. H, Zimmerman, B. J. Competence and control beliefs: distinguishing the means and ends. In P. A. Alexander, \&P. H. Winne (Eds.) Handbook of educational psychology (2nd ed.). 2006; pp: 349-368. [Link]

16. Vaughn S, Elbaum B, Boardman AG. The social functioning of students with learning disabilities: Implications for inclusion. Exceptionality. 2001 1; 9(12):47-65. [Link]

17. Yahyazadeh, Aida; Karimi, Roghayeh, \& HassanNia Jourshari, Mehdi. Level of motivation, self-reflection and attitude toward reading in dyslexic students. Quarterly mental health of the child. 2016; 3 (3): 31-42. [Persian] [Link]

18. American Psychiatric Association. Diagnostic and statistical manual of mental disorders, Yahya Seyyed Mohammadi (Trans.) First Edition, Tehran, Ravan Publication. 2013; 505-508. [Persian] [Link]

19. Polychroni F, Koukoura K, Anagnostou I. Academic self-concept, reading attitudes and approaches to learning of children with dyslexia: do they differ from their peers? European Journal of Special Needs Education. 2006, 1;21(4):415-30. [Link]

20. Barkley RA. Behavioral inhibition, sustained attention, and executive functions: constructing a unifying theory of ADHD. Psychological bulletin. 1997; 121(1):65. [Link]

21. Blair C, Razza RP. Relating effortful control, executive function, and false belief understanding to emerging math and literacy ability in kindergarten. Child development. 2007; 78(2):647-63. [Link]

22. Meltzer L, editor. Executive function in education: From theory to practice. Guilford Publications; 2018,19. [Link]

23. Holmes J, Gathercole SE, Dunning DL. Adaptive training leads to sustained enhancement of poor working memory in children. Developmental science. 2009; 12(4): F9-15. [Link]

24. Hamidi, Farideh \& Fayyazbakhsh, Marzieh. The Effectiveness of active memory training on improving reading skills of dyslexic students; Journal of Education and Evaluation Research. 2016; 9 (35): 1335. [Persian] [Link] 
25. Karimi, Somayyeh \& Askari, Saeed. The Effectiveness of training active memory strategies on improving reading performance of dyslexic students, Journal of Learning Disabilities. 2013;3 (1): 79-90. [Persian] [Link]

26. Sesma HW, Mahone EM, Levine T, Eason SH, Cutting LE. The contribution of executive skills to reading comprehension. Child Neuropsychology. 2009 17; 15(3):232-46. [Link]

27. McCloskey G, Perkins LA. Essentials of executive functions assessment. John Wiley \& Sons; 2012, 30.

[Link]

28. McCloskey, G, Gilmartin, C, Stanco Vitanza, B. Interventions for students with executive skills and executive functions difficulties. In J.T. Mascolo, V.C. Alfonso, \& D.P. Flanagan (Eds.), Essentials of planning, selecting, and tailoring interventions for unique learners. Hoboken, NJ: John Wiley \& Sons, Inc. 2014; 314-386. [Link]

29. Albert-Green DF. Teachers', parents', and students' perceptions of effective school characteristics of two Texas urban exemplary open-enrollment charter schools (Doctoral dissertation, Texas A\&M University). [Link]

30. Barkly, R. Attention -deficit hyperactivity disorder. New York: The Guilford Press. 2015 [Link]

31. Motamedi, M., Beirman, K., and Cynthia L. H-P. Rejection Reactivity, Excutive function Skills, and social adjustment prblems of Interractive and Hyperactivity Kindergarteners. Social Development. 2016: 25 (2), 322-339. [Link]

32. Kirk, S, Gallagher, G, \& Coleman, M. R. Education Exceptional Children (14 ${ }^{\text {th }}$ Ed). Congage Learning Printed in United States of America. 2015;51-59. [Link]

33. Barkley RA. Adolescents with attentiondeficit/hyperactivity disorder: An overview of empirically based treatments. Journal of Psychiatric Practice®. 2004, 1;10(1):39-56. [Link]

34. Altemeier LE, Abbott RD, Berninger VW. Executive functions for reading and writing in typical literacy development and dyslexia. Journal of clinical and experimental neuropsychology. 2008, 4; 30(5):588606. [Link]

35. Engel de Abreu PM, Abreu N, Nikaedo CC, Puglisi ML, Tourinho CJ, Miranda MC, Befi-Lopes DM, Bueno OF, Martin R. Executive functioning and reading achievement in school: a study of Brazilian children assessed by their teachers as "poor readers". Frontiers in psychology. 2014, 10; 5: 550. [Link]

36. Dias NM, Seabra AG. Intervention for executive functions development in early elementary school children: effects on learning and behaviour, and followup maintenance. Educational Psychology. 2017, 21; 37(4):468-86. [Link] 